
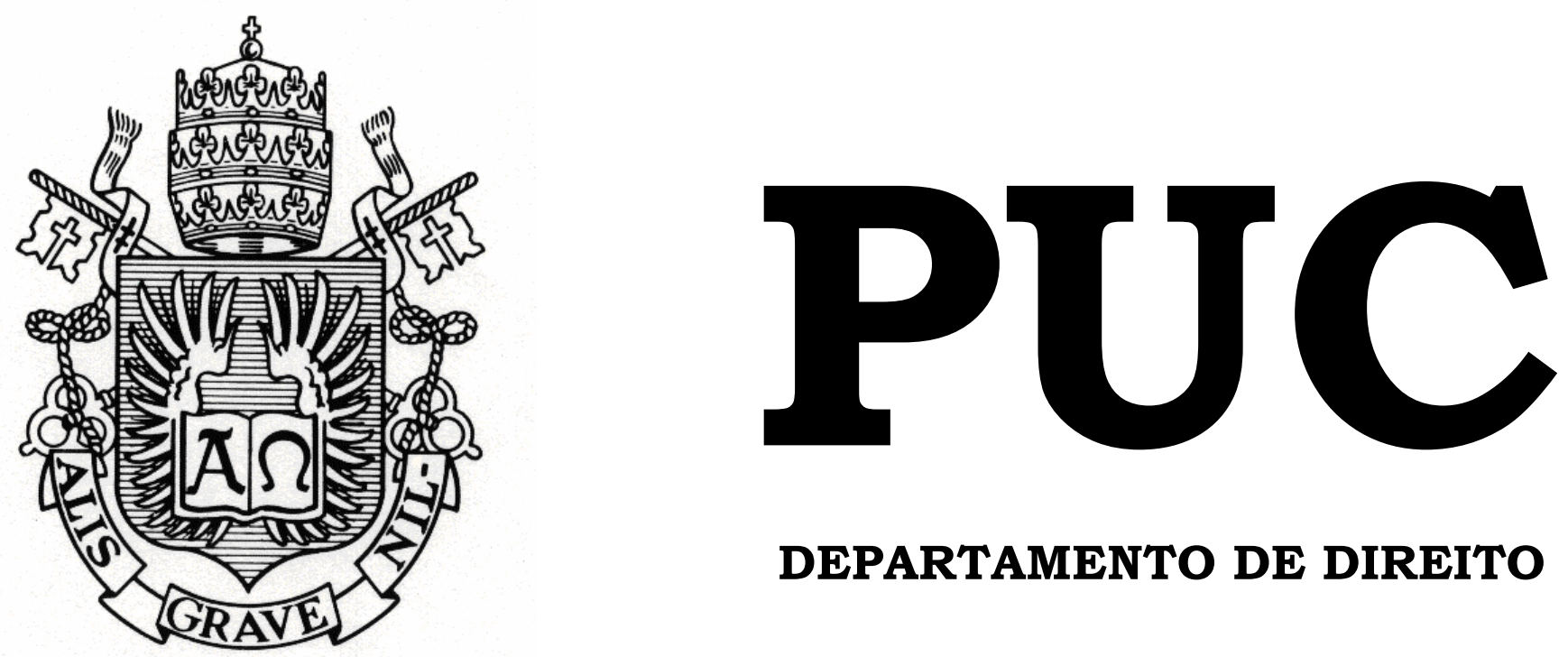

DEPARTAMENTO DE DIREITO

\title{
A JURISPRUDÊNCIA DA CORTE INTERAMERICANA DE DIREITOS HUMANOS EM MATÉRIA DE DIREITOS ECONÔMICOS, SOCIAIS E CULTURAIS
}

por

LETICIA DA COSTA PAES

ORIENTADOR(A): CAROLINA DE CAMPOS MELO 2008.1

RUA MARQUÊS DE SÃO VICENTE, 225 - CEP 22453-900 


\title{
A JURISPRUDÊNCIA DA CORTE INTERAMERICANA DE DIREITOS HUMANOS EM MATÉRIA DE DIREITOS ECONÔMICOS, SOCIAIS E CULTURAIS
}

\author{
por \\ LETICIA DA COSTA PAES
}

Monografia apresentada ao Departamento de Direito da Pontificia Universidade Católica do Rio de Janeiro (PUC-Rio) para a obtenção do Título de Bacharel em Direito.

Orientador(a):

CAROLINA DE CAMPOS MELO

2008.1 


\section{AGRADECIMENTOS}

À toda minha família, pela certeza que nos une.

À meus pais pelo amor e pelo desejo de que eu seja sempre feliz.

Ao Felipe, pelo amor e carinho de sempre.

À Silvinha que mesmo um pouco distante está sempre próxima com suas palavras de carinho.

À Maína por ter me proporcionado as maiores alegrias durante a faculdade.

À Tânia, pela força e insistência em não deixar passar-me despercebida a realidade vivida.

À minha orientadora, Carolina de Campos Melo, pela excelente orientação e, principalmente, por tornar o meu espaço universitário um lugar do livre pensar e de constante transformação.

Aos meus amigos do grupo de estudo "Simulações e Realidades", Fernanda, Raquel, Cecília, Celina, Teresa, Danielle, Luisa e Roberto, pela amizade e pela lembrança de que é possível um mundo melhor. 


\section{RESUMO}

Esta monografia tem como tema central a jurisprudência contenciosa da Corte Interamericana de Direitos Humanos (Corte Interamericana ou Corte) em matéria de direitos econômicos, sociais e culturais (DESC), e busca demonstrar os esforços deste órgão para a efetiva proteção destes direitos. O estudo pressupõe a análise dos instrumentos normativos do Sistema Interamericano de Proteção dos Direitos Humanos (Sistema Interamericano) que protegem os DESC e os obstáculos que apresentam para a plena proteção destes direitos. São analisadas as sentenças da Corte que permitem constatar a consagração da tese de indivisibilidade dos direitos humanos no Sistema Interamericano em razão da proteção dada aos DESC através do reconhecimento de violações dos direitos civis e políticos. Também é analisada a dificuldade da Corte em declarar violações autônomas dos DESC, o que deixa clara a tendência da Corte em proteger os DESC por meio dos direitos civis e políticos.

\section{PALAVRAS CHAVES}

1 - Direito Internacional dos Direitos Humanos; 2 - Sistema Interamericano de Proteção dos Direitos Humanos; 3 - Corte Interamericana de Direitos Humanos; 4 - Jurisprudência; 5 - Direitos econômicos, sociais e culturais; 


\section{SUMÁRIO}

Introdução

Capítulo I

1. Instrumentos normativos do Sistema Interamericano de Proteção dos Direitos Humanos para a proteção dos direitos econômicos sociais e culturais

1.1. Declaração Americana dos Direitos e Deveres do Homem 9

1.2. Convenção Americana sobre Direitos Humanos 12

1.2.1. A proteção dos direitos econômicos, sociais e culturais no art. 13 26 da Convenção Americana sobre Direitos Humanos

1.2.2. A aplicação de outros instrumentos internacionais através da 18

Convenção Americana sobre Direitos Humanos

1.3. Protocolo Adicional à Convenção Americana sobre Direitos

Humanos em matéria de direitos econômicos, sociais e culturais (Protocolo de San Salvador)

\section{Capítulo II}

2. A proteção dos direitos econômicos, sociais e culturais através dos direitos civis e políticos na jurisprudência da Corte Interamericana de Direitos Humanos

2.1. Direitos à saúde e à educação

2.2. Direitos aos benefícios da cultura 30

2.3. Direitos sindicais 34

2.4. Direito à previdência social 40

Capítulo III

3. Aplicação do art. 26 da Convenção Americana na jurisprudência

da Corte Interamericana de Direitos Humanos

Conclusão 


\section{ABREVIAÇÕES}

\begin{tabular}{|l|l|}
\hline Art./Arts. & Artigo/Artigos \\
\hline CORTE IDH & Corte Interamericana de Direitos Humanos \\
\hline CIDH & Comissão Interamericana de Direitos Humanos \\
\hline IIDH & Instituto Interamericano de Direitos Humanos \\
\hline OEA & Organização dos Estados Americanos \\
\hline DESC & Direitos econômicos, sociais e culturais \\
\hline ONU & Organização das Nações Unidas \\
\hline OIT & Organização Internacional do Trabalho \\
\hline OC & Opinião Consultiva \\
\hline CEJIL & Centro pela Justiça e o Direito Internacional \\
\hline
\end{tabular}




\section{INTRODUÇÃO}

O continente americano é marcado pela diversidade de raças, recursos naturais e traços culturais. À margem desse potencial, o quadro de pobreza, exclusão e miséria humana que aí se verifica faz ver uma das zonas mais contrastantes e desiguais no planeta. Devido a esta realidade continental surge cada vez mais um grande número de demandas que denunciam a vulnerabilidade dos direitos econômicos, sociais e culturais de grupos mais pobres e vulneráveis - demandas que já chegam à Comissão Interamericana de Direitos Humanos (Comissão Interamericana) e que atingem a Corte Interamericana.

Nesse contexto, com o reconhecimento do caráter fundamental dos direitos econômicos, culturais e sociais e a partir da consagração da tese de indivisibilidade dos direitos humanos no Sistema Interamericano de Proteção dos Direitos Humanos (Sistema Interamericano), são dados passos concretos em prol da implementação mais eficaz destes direitos.

Com efeito, a Corte que historicamente concentrou sua jurisprudência na defesa da vida, da integridade, das liberdades, da justiça, da igualdade e dos direitos políticos tem, apesar das dificuldades, paulatinamente decidido também em prol dos direitos econômicos, sociais e culturais.

Nesse sentido, o presente estudo traz uma análise das sentenças da Corte Interamericana em matéria de direitos econômicos, sociais e culturais. Tem como objetivo examinar a forma com que este órgão tem buscado a efetiva proteção destes direitos no âmbito de sua competência contenciosa. Eis a perspectiva segundo a qual foi planejada, estruturada e desenvolvida a presente obra, dividida em três capítulos.

O primeiro capítulo trata dos principais instrumentos normativos do Sistema Interamericano para a proteção dos DESC: a Declaração Americana sobre os Direitos e Deveres do Homem (Declaração Americana 
ou Declaração), a Convenção Americana sobre Direitos Humanos (Convenção Americana ou Convenção) e o Protocolo Adicional à Convenção Americana em matéria de Direitos Econômicos, Sociais e Culturais (Protocolo de San Salvador). Seu objetivo é o de demonstrar de que forma cada um destes instrumentos prevê a proteção dos DESC e, conseqüentemente, as oportunidades para sua justiciabilidade. Além disso, algumas discussões doutrinárias contribuem para demonstrar os aspectos controvertidos sobre a aplicação destes instrumentos no Sistema Interamericano.

No segundo capítulo são apresentados estudos de casos em que a Corte Interamericana protegeu determinados DESC, como os direitos à saúde e à educação, aos benefícios da cultura, sindicais e à previdência social, nesta ordem, por meio da interpretação cada vez mais ampla dos direitos civis e políticos. A análise destes casos demonstrará os avanços da Corte para a proteção dos DESC e confirmarão a incoerência lógica do trato diferenciado dos direitos humanos.

O terceiro capítulo trata da análise dos casos em que a Corte teve que se pronunciar acerca do art. 26 que é o único artigo sobre direitos econômicos, sociais e culturais na Convenção Americana. A abordagem que será feita ilustrará a dificuldade da Corte em estabelecer violações deste artigo e, conseqüentemente, sua tendência em evitar a proteção autônoma dos DESC.

Em resumo, serão demonstrados os esforços da Corte em prol da defesa dos direitos econômicos, sociais e culturais e suas respectivas dificuldades na consagração da justiciabilidade destes direitos.

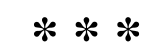




\section{CAPÍTULO I}

\section{INSTRUMENTOS NORMATIVOS DO SISTEMA INTERAMERICANO DE PROTEÇÃO DOS DIREITOS HUMANOS PARA A PROTEÇÃ̃O DOS DIREITOS ECONÔMICOS SOCIAIS E CULTURAIS}

A tutela dos direitos econômicos, sociais e culturais no Sistema Interamericano de Proteção dos Direitos Humanos é um processo em construção. Todavia, este sistema oferece as maiores oportunidades de todos os sistemas supranacionais, sejam regionais ou universais, para a justiciabilidade $^{1}$ dos referidos direitos ${ }^{2}$. Neste sentido, permite explorar vias distintas para o amparo dos DESC na esfera regional, vez que possui um marco normativo generoso e prevê uma série de ferramentas eficazes para propiciar o respeito e a vigência dos direitos humanos ${ }^{3}$.

Quanto a sua estrutura normativa, não obstante exista no sistema uma série de instrumentos ${ }^{4}$ que reconhecem de forma direta ou indireta os direitos econômicos, sociais e culturais, são três os mais importantes: a Declaração Americana dos Direitos e Deveres do Homem, a Convenção Americana sobre Direitos Humanos e o Protocolo de San Salvador.

\subsection{Declaração Americana dos Direitos e Deveres do Homem}

\footnotetext{
${ }^{1}$ De acordo com a doutrinadora Tara Melish, a justiciabilidade é "[l]a posibilidad de determinar judicialmente si un derecho protegido ha sido vulnerado o no”. Acrescenta ainda que justiciabilidade é "[...] el umbral requerido para que el reclamo que uno haga, sea estudiado ante la jurisdicción contenciosa de una Corte” (MELISH, Tara. La Protección de los Derechos Económicos, Sociales y Culturales en el Sistema Interamericano de Derechos Humanos: Manual para la Presentación de Casos [I]. Quito: Sergrafic, 2003, p. 110-115).

${ }_{2}^{2}$ MELISH, Tara. El litigio supranacional de los derechos económicos, sociales y culturales: avances y retrocesos en el Sistema Interamericano [II]. p. 175. Disponível em: $<$ http://www.bibliojuridica.org/libros/libro.htm?l=2469>. Acesso em 28 maio 2008.

3 KRSTICEVIC, Viviana. La tutela de los derechos sociales en el sistema interamericano. Disponível em: <http://www.idrc.ca/openebooks/323-2/\#page_171>. Acesso em: 28 maio 2008.

${ }^{4}$ Veja: Convenção Interamericana para Prevenir e Punir a Tortura, 9 de dezembro de 1985, OASTS n67, entrada em vigor: 28 fev. 1987, art. 8; Convenção Interamericana sobre o Desaparecimento Forçado de Pessoas, 9 de junho de 1994, OEA Doc. OEA/Ser.P AG/doc.3114/94 rev. 1, entrada em vigor: 28 mar. 1996, art. XIII; Convenção Interamericana
} 
Na celebração da Nona Conferência Internacional Americana, realizada em Bogotá, entre os dias 30 de março e 2 de maio de 1948, os Estados americanos aprovaram dois importantes instrumentos jurídicos em matéria de direitos humanos: a Carta da Organização dos Estados Americanos $^{5}$ (Carta da OEA) e a Declaração Americana dos Direitos e Deveres do Homem, aprovada em 2 de maio de $1948{ }^{6}$.

A Carta da OEA proclama os direitos fundamentais do indivíduo, sem distinção de raça, nacionalidade, crença, sexo ou cor e estabelece como um dos principais deveres dos Estados respeitar os direitos da pessoa humana ${ }^{7}$. A Declaração Americana, por sua vez, constitui um complemento indispensável à Carta da OEA, enquanto a dita Carta não especifica quais são os direitos da pessoa humana, tarefa que desenvolve a Declaração ${ }^{8}$.

A Declaração estabelece em seu corpo normativo uma lista exaustiva de direitos que os Estado membros da OEA se comprometem a respeitar e garantir. Assim como ocorre com a Declaração Universal de Direitos Humanos ${ }^{9}$, a Declaração Americana não separa os direitos econômicos, sociais e culturais dos direitos civis e políticos, dando uma noção instrumental de interdependência e indivisibilidade ${ }^{10}$. Protege assim,

para Prevenir, Punir e Erradicar a Violência contra a Mulher, 6 de junho de 1994, entrada em vigor: 5 mar. 1995, art. 12.

${ }^{5}$ A referida Carta foi assinada em 30 de abril de 1948 e está em vigor desde 13 de dezembro de 1953. Esse instrumento foi objeto de quatro importantes reformas, introduzidos pelos seguintes intrumentos: Protocolo de Buenos Aires, assinada nessa cidade em 27 de fevereiro de 1967 e em vigor desde 27 de fevereiro de 1970; pelo Protocolo de Cartagena de Índias, assinada em 5 de dezembro de 1985 e em vigor desde 16 de novembro de 1988; pelo Protocolo de Washington, assinado em 14 de dezembro de 1992 e em vigor desde 25 de setembro de 1997 e pelo Protocolo de Manágua, adotado em 6 de outubro de 1993 e em vigor desde 29 de janeiro de 1996 (LEDESMA, Héctor Faúndez. Los derechos económicos, sociales y culturales en el Sistema Interamericano. In: VOLIO, Lorena Gonzáles (Coord.). El Sistema Interamericano de Protección de los Derechos Humanos: su jurisprudencia sobre debido proceso, DESC, libertad personal y libertad de expresión. Tomo II. San José: Editorama S.A., 2004, p. 93).

${ }^{6}$ LEÃO, Renato Zerbini R. Os Direitos Econômicos, Sociais e Culturais na América Latina e o Protocolo de San Salvador. Porto Alegre: Ed. Sergio Antonio Fabris, 2001, p. 95.

${ }^{7}$ As reformas introduzidas na Carta da OEA, com a aprovação do Protocolo de Buenos Aires incorporaram novas disposições nos capítulos VII, VIII e IX da mesma, relativas aos direitos econômicos, sociais e culturais. (LEDESMA, H. Op.cit., p. 95).

${ }^{8}$ Ibid. p. 95.

${ }^{9}$ Adotada e proclamada pela Resolução 217 A (iii) da Assembléia Geral das Nações Unidas em 10 de dezembro de 1948.

10 SALVIOLI, Fabián. La protección de los derechos económicos, sociales y culturales en el sistema interamericano. In: Revista Instituto Interamericano de Direitos Humanos, San José, No. 39, jan.- jun. 2004, p. 106. 
entre outros, os direitos à saúde (art. XI), à educação (art. XII), à previdência social (art. XVI), ao trabalho com justa remuneração (art. XIV), ao descanso e seu aproveitamento (art. XV), aos benefícios da cultura (art. XIII) e outorga proteção especial para as mães, crianças (art. VII) e famílias (art. VI), assim como protege os direitos à vida, à liberdade, à seguridade $\mathrm{e}$ integridade pessoal (art. I), à igualdade (art. II), à liberdade de expressão (art. IV) e à participação política (art. XX). Nota-se que o âmbito de proteção que oferece a Declaração em matéria de direitos econômicos, sociais e culturais é muito mais específico que o conteúdo da Convenção Americana $^{11}$.

Embora a Declaração sustente, em seu preâmbulo, que a proteção internacional dos direitos do homem deve ser a orientação principal do direito americano em evolução, diferentemente da Carta da OEA, este instrumento não adotou a forma de um tratado. Por outro lado, a Corte, em sua opinião consultiva sobre a interpretação da Declaração (OC-10), reconheceu que este instrumento faz parte do sistema normativo interamericano e constitui fonte de obrigações internacionais, enquanto determina quais são os direitos que se referem à Carta da $\mathrm{OEA}^{12}$.

Nesse sentido, no que tange à competência consultiva da Corte, já foi estabelecido que sendo a Carta da OEA e a Convenção Americana tratados segundo os quais a Corte pode exercer sua competência consultiva em virtude do art. 64.1 (da Convenção), a Corte pode interpretar a Declaração Americana e emitir sobre ela opinião consultiva no marco e dentro dos limites de sua competência, quando for necessário interpretar tais instrumentos ${ }^{13}$.

\footnotetext{
${ }^{11}$ Os direitos à saúde e ao bem-estar, à educação, ao trabalho, ao descanso, à previdência social e aos benefícios da cultura não estão expressamente consagrados na Convenção Americana. Tara Melish, no entanto, defende que a Convenção Americana protege todos os direitos consagrados na Declaração Americana (MELISH, T. Op.cit. [II], p. 176).

${ }_{12}$ CORTE INTERAMERICANA DE DIREITOS HUMANOS (CORTE IDH). Opinión Consultiva OC-10/89: Interpretación de la Declaración Americana de los Derechos y Deberes del Hombre en el Marco del Artículo 64 de la Convención Americana sobre Derechos Humanos, 14 jul. 1989, par. 45.

${ }^{13}$ Ibid. par. 44.
} 
Em relação à sua competência contenciosa, a Corte precisou que geralmente considera as disposições da Declaração para interpretar a Convenção Americana. Segundo este órgão, para os Estados Partes da Convenção, a fonte concreta de suas obrigações no que diz respeito à proteção dos direitos humanos, é, em princípio, a própria Convenção. Não obstante seja a Convenção o instrumento principal que rege os Estados Partes, devem esses cumprir as obrigações que derivam da Declaração pelo fato de serem membros da $\mathrm{OEA}^{14}$.

Chistian Courtis, com base no que foi definido na OC-10, entende que:

El valor de la Declaración aparece desplazado por la Convención en cuanto instrumento de identificación de derechos justiciables ante el Sistema , por lo que tendría solo el valor de um instrumento interpretativo, que para tener pleno efecto requeríria haber identificado en un instrumento justiciable el derecho en cuestión. ${ }^{15}$

Tara Melish, por sua vez, considera que para os Estados Partes que ratificaram a Convenção Americana, este tratado "reemplaza a la Declaración como instrumento de aplicación ante peticiones individuales bajo la jurisdicción contenciosa de la Comisión y de la Corte”, e defende que todos os direitos consagrados na Declaração estão protegidos na Convenção ${ }^{16}$.

No que se refere à Comissão Interamericana de Direitos Humanos, os arts. 1.2.b) e 20 de seu Estatuto ${ }^{17}$, o art. 23 e o capítulo III de seu

\footnotetext{
${ }^{14}$ Cf. art. 29 da Convenção Americana sobre Direitos Humanos; e CORTE IDH. Opinión Consultiva OC-10/89. par. 36-46.

${ }^{15}$ v. ABRAMOVICH, Victor e COURTIS, Christian apud BRICEÑO-DONN, Marcela; HURTADO, Michael Reed. Aportes para el litigio en materia de derechos económicos, sociales y culturales en el sistema interamericano de protección. Documento de trabalho produzido para a Plataforma Interamericana de Direitos Humanos, Democracia e Desenvolvimento, Bogotá, out. 2007, p. 10.

${ }^{16}$ MELISH, T. Op.cit. [II], p. 176.

${ }^{17}$ Art. 1.2: Para os fins deste Estatuto, entende-se por direitos humanos: [...] b) os direitos consagrados na Declaração Americana de Direitos e Deveres do Homem, com relação aos demais Estados Membros. Art. 20: Com relação aos Estados Membros da Organização que não são Partes da Convenção Americana sobre Direitos Humanos, a Comissão terá, além das atribuições assinaladas no "artigo 18", as seguintes: a) Dispensar especial atenção à tarefa da observância dos Direitos Humanos mencionados nos "artigos 1, 2, 3, 4, 8, 25 e 26" da Declaração Americana dos Direitos e Deveres do Homem (Estatuto da Comissão Interamericana de Direitos Humanos - grifos do original)
} 
regulamento ${ }^{18}$ definem a competência da mesma com respeito aos direitos humanos enunciados na Declaração. No entanto, a utilização deste instrumento pela Comissão foi inconsistente. Em alguns casos manifestou que a Declaração é vinculante para os Estados membros da OEA que não tenham ratificado a Convenção. Em contraposição, nos casos em que os Estados eram partes da Convenção, a Comissão integrou as normas da Declaração com as da Convenção Americana. Em outra ocasião, afirmou ser competente para declarar violações deste instrumento quando os direitos violados não se encontram previsto na Convenção ${ }^{19}$.

Conclui-se, portanto, que existem obstáculos substanciais que historicamente impediram a aplicação eficaz da Declaração Americana. Contudo, a Declaração é um instrumento valioso para a interpretação da Convenção Americana e, conseqüentemente, para a proteção dos direitos econômicos, sociais e culturais.

\subsection{Convenção Americana sobre Direitos Humanos}

\section{A Convenção Americana sobre Direitos Humanos ${ }^{20}$, também} conhecida como Pacto de San José, refere-se principalmente aos direitos civis e políticos (Capítulo II) e, diferentemente da Declaração Americana, dedica um único artigo (art. 26), em seu capítulo III, sobre a proteção dos direitos econômicos, sociais e culturais ${ }^{21}$. Importante frisar que entre os direitos civis e políticos foram incluídos na Convenção direitos relativos à

\footnotetext{
${ }^{18}$ Art. 49, capítulo III: A Comissão receberá e examinará a petição que contenha denúncia sobre presumidas violações dos direitos humanos consagrados na Declaração Americana dos Direitos e Deveres do Homem com relação aos Estados membros da Organização que não sejam partes na Convenção Americana sobre Direitos Humanos. (Regulamento da Comissão interamericana de Direitos Humanos).

19 Centro pela Justiça e o Direito Internacional (CEJIL). La Proteccion de los Derechos Económicos, Sociales y Culturales y el Sistema Interamericano. Costa Rica: Gossestra Intl., S.A, 2005. p. 70-71.

20 Adotada na Conferência Especializada Interamericana sobre Direitos Humanos, celebrada na cidade de San José, Costa Rica, de 7 a 22 nov. 1969. Entrada em vigor: 18 jul. 1978.

${ }^{21}$ Tara Melish defende que a Convenção protege uma gama ampla de direitos econômicos, sociais e culturais, direta e indiretamente, embora freqüentemente a doutrina caracterize a Convenção Americana como um tratado de direitos “civis e políticos”. (MELISH, Tara. The Inter-American
} 
liberdade de associação (art. 16), à proteção da família (art. 17), à proteção das crianças (art. 19) e à propriedade privada (art. 21) que têm evidentes conotações econômicas e sociais ${ }^{22}$.

Embora os direitos estejam dispostos em capítulos separados intitulados "Direitos Civis e Políticos" e "Direitos Econômicos, Sociais e Culturais”, a Convenção reitera em seu preâmbulo que de acordo com a Declaração Americana, o "ideal do ser humano livre isento do temor e da miséria” só poderá ser realizado se forem criadas condições que permitam a cada pessoa gozar dos seus "direitos econômicos, sociais e culturais, bem como de seus direitos civis e políticos.” Assim, pode-se afirmar que a Convenção é um importante instrumento para a proteção dos direitos econômicos, sociais e culturais.

\title{
1.2.1. A proteção dos direitos econômicos, sociais e culturais no artigo 26 da Convenção Americana sobre Direitos Humanos
}

Os direitos econômicos, sociais e culturais estão consagrados na Convenção de uma forma muito genérica. Assim prevê o art. 26:

\begin{abstract}
Os Estados-partes comprometem-se a adotar as providências, tanto no âmbito interno, como mediante cooperação internacional, especialmente econômica e técnica, a fim de conseguir progressivamente a plena efetividade dos direitos que decorrem das normas econômicas, sociais e sobre educação, ciência e cultura, constantes da Carta da Organização dos Estados Americanos, reformada pelo Protocolo de Buenos Aires, na medida dos recursos disponíveis, por via legislativa ou por outros meios apropriados.
\end{abstract}

Observa-se que este artigo refere-se à obrigação dos Estados de adotar medidas para o "desenvolvimento progressivo" com o intuito de dar plena efetividade aos direitos que derivam da Carta da $\mathrm{OEA}^{23}$, não estabelecendo quais são estes direitos. Muito embora a Corte, em sua competência consultiva, tenha proclamado que a Declaração Americana é o

Court of Human Rights: Beyond Progressivity [III]. Disponível em: $<$ http://ssrn.com/abstract=1000265>. Acesso em: 28 maio 2008.

${ }^{22}$ LEDESMA H. Op.cit., p. 98-99. 
instrumento que contém e define os direitos humanos referidos na $\operatorname{Carta}^{24}$, a mesma não estabeleceu claramente quais as pautas a serem utilizadas para determinar os direitos consagrados no art. 26 e o seu alcance.

Com efeito, a determinação do alcance deste artigo tem gerado diversos debates doutrinários, a saber: (i) se a Convenção Americana consagra direitos econômicos, sociais e culturais exigíveis; (ii) quais são os direitos a que faz alusão o art. 26; (iii) quais as obrigações dos Estados em relação a estes direitos.

Sobre o primeiro debate sustenta-se, por um lado, que a ênfase ao “desenvolvimento progressivo" priva os DESC de justiciabilidade de tal forma que haveria de entendê-los exclusivamente como objetivos programáticos. Ainda considera-se que "os direitos" consagrados na Carta da OEA não seriam "direitos em stricto sensu” 25.

Segundo Cançado Trindade, "as normas econômicas, sociais e culturais na Carta da OEA não visavam propriamente proteger ou garantir direitos humanos, mas antes determinar objetivos ou linhas de conduta para os Estados membros neste domínio"26 ${ }^{26}$ Com efeito, Héctor Gros Espiell ao criticar a não inclusão de cada um dos direitos econômicos, sociais e culturais na Convenção Americana, sustentou que:

El error consistió en no comprender que las normas económicas, sociales y culturales del Protocolo de Buenos Aires, aunque enumeraban derechos económicos, sociales y culturales no tenían como objetivo aclarar y garantizar derecho humanos sino fijar pautas de conducta de los Estados en materia económica, social y cultural ${ }^{27}$

Por sua vez, Manuel Ventura Robles, após analisar os antecedentes e os trabalhos preparatórios da Convenção Americana, considerou que os

\footnotetext{
${ }^{23}$ A referência é aos capítulos XII, XIII e IX da Carta da OEA, relativos aos direitos econômicos, sociais e culturais.

${ }^{24}$ CORTE IDH. Opinión Consultiva OC-10/89, pars. 43- 45.

25 INSTITUTO INTERAMERICANO DE DERECHOS HUMANOS (IIDH). Protección Internacional de los Derechos Económicos Sociales y Culturales: Sistema Internacional y Sistema Interamericano, San José: Editorama S.A., 2008. p. 81.

${ }^{26}$ CANÇADO TRINDADE, Antônio Augusto. Tratado de Direito Internacional dos Direitos Humanos volume I. $2^{\mathrm{a}}$ edição. Porto Alegre: Sergio Antonio Fabris Editor, 2003, p. 460.

${ }_{27}$ GROS ESPIELL, Héctor. Los derechos económicos, sociales y culturales em el Sistema Interamericano. San José, 1986, apud IIDH. Op.cit., p. 81.
} 
direitos em pauta não foram incluídos na mesma. Foi por este motivo que a jurisprudência da Corte fez menção aos DESC a partir da violação dos direitos civis e políticos, constatou o juiz da Corte Interamericana ${ }^{28}$.

Por outro lado, Victor Abramovich e Julieta Rossi ressaltam que o art. 26 alude claramente à “adoção de medidas” para dar "plena efetividade” a “direitos”. Diante de uma interpretação literal o artigo, portanto, não enuncia meros objetivos programáticos ${ }^{29}$.

O juiz da Corte Sergio García Ramírez também assinalou que o art. 26 contempla direitos e acrescentou que "[t]odos los derechos [...] contenidos en el Pacto de San José y aceptados por los Estados [...] se hallan sujetos al régimen general de supervisión y decisión, o dicho de otra manera, a los “médios de protección” 30.

Fabián Salvioli sustenta que é plenamente exigível a adoção de medidas para o desenvolvimento progressivo dos direitos econômicos, sociais e culturais ${ }^{31}$. Para Tara Melish, o art. 26 se refere a um conjunto de direitos completamente protegidos que os Estados têm a obrigação de garantir da mesma maneira que todos os demais direitos consagrados na Convenção Americana ${ }^{32}$.

Se aceita a idéia de que o art. 26 consagra obrigações estatais relativas aos direitos econômicos, sociais e culturais, passa-se ao segundo debate relativo à identificação dos direitos a que faz alusão o referido $\operatorname{artigo}^{33}$.

\footnotetext{
${ }^{28}$ ROBLES, Manuel Ventura. Jurisprudencia de la Corte Interamericana de Derechos Humanos en materia de derechos económicos, sociales y culturales. In: Revista Intistituto Interamericano de Derechos Humanos. San José, No. 40, 2004, p. 91 e 130.

${ }^{29}$ ABRAMOVICH, Víctor e ROSSI, Julieta. La tutela de los derechos económicos, sociales y culturales en el artículo 26 de la Convención Americana sobre Derechos Humanos. p. 40. Disponível em: $<$ http://dialnet.unirioja.es/servlet/articulo?codigo=2354628 $>$. Acesso em: 28 maio 2008.

${ }^{30}$ RAMÍREZ, Sergio García. Protección jurisdiccional internacional de los derechos económicos, $\begin{array}{llllll}\text { sociales } & y & \text { culturales. } & \text { p. } & 139-141 . & \text { Disponível em: }\end{array}$ $<$ http://dialnet.unirioja.es/servlet/articulo?codigo=624566>. Acesso em: 28 maio 2008.

${ }^{31}$ SALVIOLI, F. Op.cit., p. 112.

${ }^{32}$ MELISH, T. Op.cit. [I], p. 379-382.

${ }^{33}$ Importante destacar que a Comissão Interamericana definiu alguns direitos econômicos, sociais e culturais que estão previstos no art. 26 no marco dos informes de países e dos informes sobre casos individuais (Veja: COMISSÃO INTERAMERICANA DE DIREITOS HUMANOS (CIDH). Tercer informe sobre la situación de los derechos humanos en Colombia. OEA/Ser.L/V/II.102
} 
Dentre as posições sobre os direitos que derivam do art. 26 encontram-se interpretações, como a de Julieta Rossi e Víctor Abramovich, que defendem como direitos incluídos na norma apenas aqueles que possam derivar da Carta da OEA, sem que se possa utilizar a Declaração Americana ou o princípio pro persona ${ }^{34}$ para sua determinação. Segundo esta postura, o princípio de interpretação mais favorável só deve ser utilizado para fixar o alcance da respectiva norma ${ }^{35}$. Outras posições, como as de Tara Melish, Viviana Krsticevic e Fabián Salvioli, sustentam que, mediante a aplicação da interpretação mais favorável, e à luz do art. 29.d) da Convenção ${ }^{36}$, os direitos do art. 26 são determinados pela análise unificada da Carta da OEA, da Declaração Americana ${ }^{37}$ e do Protocolo de San Salvador assim como de outros instrumentos internacionais pertinentes à matéria ${ }^{38}$.

Por último, a propósito das obrigações que derivam do art. 26, a Convenção Americana enuncia, em seus dois primeiros artigos, obrigações gerais ("respeitar”, “garantir” e, em função desse último dever, “adotar medidas”). Logo, em seu segundo capítulo, refere-se, como visto, aos direitos civis e políticos sem enunciar deveres de tal caráter. Posteriormente, no capítulo terceiro, a Convenção prevê obrigações gerais relativas aos direitos econômicos, sociais e culturais (adotar as providências [...] a fim de conseguir progressivamente a plena efetividade dos direitos). Surge a dúvida então, se as obrigações dos arts. $1^{\circ}$ e $2^{\circ}$ da Convenção são

Doc. 9 rev. 1, 26 fev 1999, Capítulo III, par. 4; Informe No. 29/01, Caso 12.249, Jorge Odir Miranda Cortez., El Salvador, 7 mar. 2001).

${ }^{34}$ Se existem posições de conflito ou dúvida, a Corte assinalou que ao interpretar a Convenção deve sempre eleger a alternativa mais favorável para a tutela dos direitos protegidos nesse instrumento, segundo o princípio da norma mais favorável ao ser humano (entre muito outros, CORTE IDH. Caso Trabajadores Cesados del Congreso (Aguado Alfaro y otros) vs. Perú. Excepciones Preliminares, Fondo, Reparaciones y Costas. Sentença 24 de Nov. de 2006. par. 77).

${ }^{35}$ ABRAMOVICH, Víctor e ROSSI, Julieta. Op.cit., p. 46- 53.

${ }^{36}$ Segundo o art. 29.d): Nenhuma disposição da presente Convenção pode ser interpretada no sentido de excluir ou limitar o efeito que possam produzir a Declaração Americana dos Direitos e Deveres do Homem e outros atos internacionais da mesma natureza.

${ }^{37}$ Entre as opções de litígio defendidas pelo Centro pelo CEJIL encontra-se a utilização do padrão definido pela Corte em sua Opinião Consultiva sobre a Declaração Americana, segundo a qual, "[l]a Declaración Americana determina los derechos a los que se refiere la Carta de la OEA.” O CEJIL considera que "los derechos protegidos por la Carta, a que se refiere el artículo 26, serían aquellos contenidos en la Declaración Americana”. (CEJIL. Op.cit., p. 75).

38 MELISH, T. Op.cit. [I], p. 379; KRSTICEVIC, Viviana. Op.cit.; IIDH. Op.cit., p. 86; SALVIOLI, Fabián. Op. cit. p. 112. 
ou não aplicáveis aos direitos econômicos, sociais e culturais consagrados na mesma ${ }^{39}$.

Sergio García Ramírez assinala que as obrigações gerais contidas nos arts. $1^{\circ}$ e $2^{\circ}$ compreendem todos os direitos consagrados pelo tratado e não apenas aqueles previstos no segundo capítulo ${ }^{40}$. A mesma postura é adotada por Christian Courtis ao deduzir que estes artigos ao não distinguirem a quais direitos se referem, também não deverá fazê-lo o intérprete. E mais: assinala que estas normas referem-se a direitos e liberdade reconhecidos na Convenção, por isso não devem ser consideradas apenas em relação ao capítulo dois. Acrescenta o autor que:

[L]o que agrega el artículo 26 -y por eso se trata de un caso de lex specialis en relación con el artículo 2- es que el Estado puede concretar la garantía de esos derechos -es decir, en los términos coincidentes de los artículos 2 y 26, el logro de su efectividad- en forma progresiva, $y$ en la medida de los recursos disponibles. $^{41}$

A juíza da Corte, Cecília Medina Quiroga, aceita esta posição e acredita que também se deve considerar o princípio da interpretação mais favorável. Por outro lado, constata que o art. 26 estabelece uma obrigação similar ao art. $2^{\circ}$ da Convenção (ambos estabelecem o dever de adotar medidas positivas), mas com qualificações próprias - progressividade e possibilidades econômicas. Por isso, a juíza sugere a possibilidade dos direitos econômicos, sociais e culturais terem sido concebidos com um regime de obrigações distintas dos direitos civis e políticos. Uma solução, segundo a juíza, seria sustentar que o que se deve garantir e respeitar é o dever de progressividade, embora assinale que:

\footnotetext{
${ }^{39}$ IIDH. Op.cit., p. 90.

${ }^{40}$ RAMÍREZ, S. Op.cit., p. 139.

${ }^{41}$ COURTIS, Christian. La protección de los derechos económicos, sociales y culturales a través del artículo 26 de la Convención Americana sobre Derechos Humanos. San José, 2007, apud IIDH. Op.cit., p. 90- 91.
} 
[L]a aplicación o no aplicación de las obligaciones generales de los artículos 1 y 2 no parece ayudar al progreso de los derechos económicos, sociales y culturales si el objeto del respeto y garantía es la progresividad de éstos. ${ }^{42}$

Para polemizar a questão, vale ressaltar o entendimento de Tara Melish que destaca ser imprescindível a mudança na argumentação, vez que não há que se falar em termos de progressividade. A obrigação de progressividade, segundo Melish, só pode ser avaliada mediante sistemas de monitoramento que servem para analisar a situação geral referente ao gozo de determinado direito, e não é alegável em casos individuais. Nas palavras da autora:

[E]s imprescindible que nosotros quienes litigamos en el SIA [Sistema Interamericano] utilicemos los mismos estándares en relación con los DESC que utilizamos en relación con todos los otros derechos, es decir en relación con los derechos en el Capitulo II de la Convención — los denominados "civiles y políticos”: las obligaciones del respeto y garantía según los Artículos 1 y 2 de la Convención. (Grifou-se). ${ }^{43}$

A leitura do art. 26 da Convenção, portanto, tem oscilado entre aquelas posições que historicamente consideraram esta norma como não operante, limitando-a a uma simples expressão de objetivos programáticos e não de obrigações legais vinculantes (ou direitos passíveis de justiciabilidade) e novas posições doutrinárias que defendem a tese de que este artigo consagra direitos exigíveis, introduzindo novos debates acerca do mesmo.

\subsubsection{A aplicação de outros instrumentos internacionais através da Convenção Americana sobre Direitos Humanos}

O art. 29.b da Convenção proíbe à Corte Interamericana interpretar qualquer disposição da Convenção no sentido de limitar o gozo e o exercício de qualquer direito ou liberdade que possam ser reconhecidos em

\footnotetext{
${ }^{42}$ QUIROGA, Cecília Medina. Las obligaciones de los Estados bajo la Convención Americana de Derechos Humanos. In: La Corte Interamericana de Derechos Humanos. Un cuarto de siglo 19792004. San José, C.R.: Corte IDH, 2005, p. 227- 228.

${ }^{43}$ MELISH, T. Op.cit. [II], p. 213.
} 
virtude de leis de qualquer dos Estados Partes ou em virtude de Convenções em que sejam partes os mesmos. Com efeito, a Corte pode considerar indiretamente, no âmbito de sua competência contenciosa, outros tratados ou instrumentos que protejam direitos econômicos, sociais e culturais, como o Pacto Internacional de Direitos Econômicos, Sociais e Culturais $(\text { PIDESC })^{44}$, a Convenção sobre os Direitos da Criança ${ }^{45}$ e as Convenções da Organização Internacional do Trabalho (OIT).

Ao encontrar no art. 29 uma "amplitud innovadora [...] sin paragón en ningún otro documento internacional”, o ex-juiz da Corte Interamericana, Rodolfo Piza Escalante, considerou que a norma incorpora na Convenção Americana os princípios de outros instrumentos internacionais, dos próprios ordenamentos internos e das tendências vigentes em matéria de direitos humanos ${ }^{46}$. Isso significa na prática que ao determinar o real alcance das disposições da Convenção em um contexto nacional concreto, as leis internas de um Estado parte e o tratado aplicado a ele são regularmente considerados ${ }^{47}$. A Corte reconheceu expressamente que tal prática está perfeitamente ajustada ao objeto e fim da Convenção ${ }^{48}$.

Conseqüentemente, a Corte pode considerar o direito interno, o direito consentudinário e uma série de instrumentos internacionais para determinar o alcance e conteúdo da Convenção Americana. Ainda, as decisões do Comitê de direitos humanos da ONU, da Corte Européia de Direitos Humanos e de alguns Comitês da OIT podem, da mesma forma, serem utilizadas.

\footnotetext{
${ }^{44}$ Adotado pela Resolução da Assembléia da Geral n. ${ }^{0}$ 2200-A (XXI) das Nações Unidas de 16 de Dezembro de 1966. Entrada em vigor: 3 jan. 1976.

${ }^{45}$ Adotada pela Resolução n. L 44 (XLIV) da Assembléia Geral das Nações Unidas, em 20 de novembro de 1989. Entrada em vigor: 2set. 1990.

${ }^{46}$ CORTE IDH. Opinión Consultiva OC- 4/84. Propuesta de Modificación a la Constitución Política de Costa Rica Relacionada con la Naturalización. Voto Separado del Juez Rodolfo E. Piza Escalante. 19 de jan. 1984, par. 2.

47 "La redacción de esta disposición [art. 29] está hecha con el criterio central de que no se entienda que la misma [Convenção Americana] tuvo por objeto, de alguna manera, permitir que los derechos y libertades de la persona humana pudieran ser suprimidos o limitados, en particular aquellos previamente reconocidos por un Estado" (Ibid. par. 20 - grifou-se).

${ }^{48}$ CORTE IDH. Opinión Consultiva OC-1/82. “Otros Tratados” Objeto de la Función Consultiva de la Corte (art. 64 Convención Americana sobre Derechos Humanos). 24 set. 1982, par. 43.
} 
Essa prática é utilizada pela Corte e respaldada pela compreensão de que a Convenção é um instrumento vivo, cuja interpetação deve acompanhar a evolução e as condições de vida atuais ${ }^{49}$. Segundo a Corte, a interpretação dos direitos deve ser realizada “en el marco de la evolución de los derechos fundamentales de la persona humana en el derecho internacional contemporâneo” ${ }^{\text {"50 }}$. Esta característica interpretativa utilizada pela Corte é vital para a inclusão progressiva de diretrizes que determinem o alcance e conteúdo dos direitos econômicos, sociais e culturais no Sistema Interamericano.

\subsection{Protocolo Adicional à Convenção Americana sobre Direitos Humanos em Matéria de Direitos Econômicos, Sociais e Culturais (Protocolo de San Salvador)}

A adoção em 1988 do Protocolo de San Salvador ${ }^{51}$ finalmente supriu a lacuna histórica do Sistema Interamericano relativa à proteção dos direitos econômicos, sociais e culturais ${ }^{52}$. O Protocolo invoca em seu preâmbulo, inter lia, a "estreita relação" existente entre a vigência dos direitos econômicos, sociais e culturais e a dos direitos civis e políticos formando um “todo indissolúvel”. Assim, como indica Zerbini Leão, o preâmbulo do Protocolo "constitui um elemento vital para a tese da integralidade e indivisibilidade dos direitos humanos ${ } 53$.

O Protocolo estabelece ainda, em seu art. $1^{\mathrm{o}}$, que:

Os Estados Partes neste Protocolo Adicional à Convenção Americana sobre Direitos Humanos comprometem-se a adotar as medidas necessárias, tanto de ordem interna como por meio da cooperação entre os Estados, especialmente econômica e técnica, até o máximo dos recursos disponíveis e levando em conta seu grau de desenvolvimento, a fim de conseguir, progressivamente e de acordo

\footnotetext{
${ }^{49}$ CORTE IDH. Opinión Consultiva OC-17/02. Condición Jurídica y Derechos Humanos del Niño. 28 ago. 2002, par. 193; Opinión Consultiva OC-16/99. El Derecho a la Información sobre la Asistencia Consular en el Marco de las Garantías del Debido Proceso Legal. 1 out. 1999, par. 114.

${ }_{50}$ CORTE IDH. Opinión Consultiva OC-16/99, par. 114; Opinión Consultiva OC-18/03. Condición Jurídica y Derechos de los Migrantes Indocumentados. 17 set. 2003, par. 120.

${ }^{51}$ Aprovado e assinado em San Salvador, El Savador, na XVIII Assembléia Geral da OEA em 17 de novembro de 1988. Entrada em vigor: 16 de novembro de 1999.

${ }^{52}$ CANÇADO TRINDADE, A. Op.cit., p. 461.

${ }^{53}$ LEÃO, R. Op.cit., p. 112.
} 
com a legislação interna, a plena efetividade dos direitos reconhecidos neste Protocolo.

A não admissão de restrições aos direitos reconhecidos, ou vigentes, em um Estado em razão de sua legislação interna, ou qualquer outra convenção internacional, por motivos de reconhecimento, ou não do Protocolo, está prevista em seu art. $4^{\circ}$.

O referido instrumento enuncia uma lista detalhada de direitos econômicos, sociais e culturais, a saber: ao trabalho (art. 6), condições justas, eqüitativas e satisfatórias de trabalho (art. 7), direitos sindicais (art. 8), direito à previdência social (art. 9), à saúde (art. 10), a um meio ambiente sadio (art. 11), à alimentação (art. 12), à educação (art. 13), aos benefícios da cultura (art. 14), à constituição e proteção da família (art. 15), direito da criança (art. 16), proteção de pessoas idosas (art. 17) e proteção de deficientes (art. 18).

Embora o Protocolo constitua claramente o documento do Sistema Interamericano que enuncia os direitos econômicos, sociais e culturais da forma mais ampla e detalhada, ainda é insuficiente para a proteção destes direitos, particularmente no que se refere a sua justiciabilidade ${ }^{54}$. Neste sentido, o Protocolo em seu art. 19.6, com um critério fortemente restritivo, abre a via do sistema de petições individuais previsto na Convenção Americana apenas nos casos de violações dos arts. 8.1.a e 13 que se referem a determinados direitos sindicais e ao direito à educação, respectivamente, nos casos em que forem violados por uma ação imputável diretamente ao Estado.

De acordo com o art. 8.1.a, em observância com o art. 19.6 do Protocolo, são passiveis de justiciabilidade a liberdade dos trabalhadores de organizar sindicatos (que já era amparada pelo art. 16 da Convenção Americana sobre a liberdade de associação) e dos sindicatos - que é a projeção coletiva de um direito individual, assim reconhecida explicitamente pelo Protocolo - para formar federações e confederações

\footnotetext{
${ }^{54}$ LEDESMA, H. op.cit., p. 101.
} 
nacionais e associar-se às já existentes, bem como formar organizações sindicais internacionais e associar-se livremente.

Quanto ao direito à educação, ficam sujeitas à jurisdição da Corte todas as previsões do art. 13 do Protocolo. Entre elas inclui-se o sentido geral do processo educativo e seus compromissos axiológicos (art. 13.2). Nesse marco surge também uma possível projeção coletiva de um direito individual - não qualificado expressamente com esse título pelo Protocolo , quando se aceita a liberdade de entidades, e não só de pessoas, para estabelecer e dirigir instituições de ensino (art. 13. 5).

Essa limitada capacidade normativa de exigir judicialmente os direitos econômicos, sociais e culturais por meio do Protocolo implicaria a necessidade dos litigantes recorrerem ao art. 26 da Convenção para possibilitar a proteção destes direitos. $\mathrm{O}$ art. 26, assim como todas as outras disposições da Convenção, está sujeito às normas de interpretação do art. 29 da Convenção que proporciona um mecanismo para aplicar tanto direta quanto indiretamente as disposições sobre direitos humanos contemplados em outros tratados além da Convenção. Neste sentido, à luz do princípio da interpretação mais favorável, os direitos previstos de forma genérica no art. 26, poderiam ter seu conteúdo estabelecido com base no Protocolo de San Salvador ${ }^{55}$.

\footnotetext{
${ }^{55}$ Ver nesse sentido: MELISH, T. Op.cit. [I], pp. 114- 115; BONILLA, Carlos Rafael Urquilla. Los derechos económicos, sociales y culturales en el contexto de la reforma al sistema interamericano de protección de los derechos humanos. In: Revista Interamericana de Derechos Humanos. No 31.31, San José, 1999, p. 268.
} 


\section{CAPÍTULO II}

\section{A PROTEÇÃO DOS DIREITOS ECONÔMICOS, SOCIAIS E CULTURAIS ATRAVÉS DOS DIREITOS CIVIS E POLÍTICOS NA JURISPRUDÊNCIA DA CORTE INTERAMERICANA DE DIREITOS HUMANOS}

Todos os direitos humanos sejam civis e políticos, econômicos, sociais e culturais estão intimamente ligados entre si, já que são interdependentes e indivisíveis, tal como estabelece o próprio Protocolo de San Salvador em seu preâmbulo. Neste sentido, a própria Corte afirmou que os DESC têm a mesma natureza substancial que os direitos civis e políticos. Todos derivam da essencial dignidade do ser humano e todos devem ser objeto de promoção, garantia e proteção a nível nacional, regional e internacional ${ }^{56}$.

Diante disso, a Corte, em muitos casos, ao interpretar os direitos civis e políticos analisou elementos característicos dos direitos econômicos sociais e culturais, assim como muitas das medidas impostas aos Estados por esse órgão afetaram de alguma forma esta categoria de direitos ${ }^{57}$. Desta forma, a Corte tem realizado avanços importantes para a proteção dos referidos direitos.

Feitas essas considerações, serão analisadas algumas sentenças da Corte Interamericana que exemplificarão a forma com que este órgão tem buscado a proteção dos direitos socioeconômicos e culturais e que confirmarão a incoerência do trato compartimentalizado dos direitos humanos.

\subsection{Direitos à saúde e à educação}

Aspectos essenciais dos direitos à saúde, educação, recreação, salubridade, alimentação, água potável e moradia adequada vêm sido

\footnotetext{
${ }^{56}$ CORTE IDH. Informe Anual de la Corte Interamericana de Derechos Humanos 1986, OEA/Ser.L/III, 15 Doc. 13, 1986, p. 42, par. 2.

${ }^{57}$ ROBLES, M. Op.cit., p. 107.
} 
tratados em diversos casos pela Corte a partir do conceito amplamente definido do “direito à vida” (art. $4^{\circ}$ da Convenção) e, mais especificamente, do "direito a desenvolver um projeto de vida"58. O mesmo ocorre em relação ao direito à integridade pessoal (art. $5^{\circ}$ da Convenção).

Esta linha jurisprudencial foi inicialmente reconhecida no caso Niños de la Calle (Villagran Morales) vs. Guatemala ${ }^{59}$, de 1999, referente à execução extrajudicial de crianças de rua que viviam em situação de pobreza, e assim privados dos meios básicos de subsistência. Trata-se de um caso emblemático, pois é o primeiro caso de meninos de rua que chega a um tribunal internacional ${ }^{60}$. A Corte desenvolveu uma interpretação ampla do direito à vida e do direito da criança, consagrados respectivamente nos art. $4^{\circ}$ e 19 da Convenção Americana, incluindo a idéia de um “projeto de vida” e “do acesso a condições que garantam uma existência digna” ${ }^{61}$. De acordo com a Corte, o direito à vida, frente ao qual não são admissíveis enfoques restritivos, incluí:

el derecho a que no se le impida el acceso a las condiciones que le garanticen una existencia digna. Los Estados tienen la obligación de garantizar la creación de las condiciones que se requieran para que no se produzcan violaciones de ese derecho básico y, en particular, el deber de impedir que sus agentes atenten contra él ${ }^{62}$.

As violações a este direito têm um peso maior quando se trata de crianças em "situação de risco”, para as quais os Estados têm a obrigação,

\footnotetext{
${ }^{58}$ De acordo com a Corte, o "projeto de vida" "[...] se asocia al concepto de realización personal, que a su vez se sustenta en las opciones que el sujeto puede tener para conducir su vida y alcanzar el destino que se propone. En rigor, las opciones son la expresión y garantía de la libertad. Difícilmente se podría decir que una persona es verdaderamente libre si carece de opciones para encaminar su existencia y llevarla a su natural culminación. Esas opciones poseen, en sí mismas, un alto valor existencial. Por lo tanto, su cancelación o menoscabo implican la reducción objetiva de la libertad y la pérdida de un valor que no puede ser ajeno a la observación de [la] Corte" (CORTE IDH. Caso Loayza Tamayo vs. Perú. Reparaciones y Costas. Sentença de 27 de novembro de 1998, par. 148).

${ }^{59}$ CORTE IDH. Caso de los "Niños de la Calle" (Villagrán Morales y otros) vs. Guatemala. Fondo. Sentença de 19 de novembro de 1999.

${ }^{60}$ LEÃO. Renato Zerbini R. Op.cit., p. 127.

${ }^{61}$ CORTE IDH. Caso de los "Niños de la Calle" (Villagrán Morales y otros) vs. Guatemala, pars. 144 e 191.

${ }^{62}$ Ibid. par. 144.
} 
de acordo com o art. 19 da Convenção Americana ${ }^{63}$, de evitar que sejam expostas a miséria, para não privá-las das condições minímas que as permitam viver com dignidade ${ }^{64}$. Com efeito, quando há crianças envolvidas, a Corte tem interpretado o art. $4^{\circ}$ e 19 da Convenção de forma a incluir crescentes proteções aos DESC para os grupos em situação de risco.

Esta linha jurisprudencial da Corte foi reiterada e ampliada em outras decisões. A saúde e a educação, como atributos essenciais para o direito à vida e o "direito ao projeto de vida", foram melhor fixados na jurisprudência da Corte de 2004, no caso do Instituto de Reeducación del Menor vs. Paraguai ${ }^{65}$, que também envolve crianças. A Corte considerou que as condições de detenção degradantes, as quais ficaram expostos todos os internos do Instituto, afetaram a sua saúde mental, repercutindo de forma desfavorável no desenvolvimento psíquico de sua vida e integridade pessoal. Com isso, o Tribunal reiterou que uma correta interpretação dos arts. $4^{\circ}, 5^{\circ}$ e 19 da Convenção Americana deveria ser feita à luz das disposições pertinentes da Convenção sobre os Direitos das Crianças e do Protocolo de San Salvador, já que estes instrumentos e a Convenção Americana formam parte do corpus juris internacional de proteção das crianças, no que concerne - entre outras coisas - à especial supervisão periódica no âmbito da saúde e implementação de programas de educação ${ }^{66}$. Além disso, a Corte não vacilou em citar o Comitê dos Direitos das Crianças ${ }^{67}$ para interpretar o conceito de "desenvolvimento da criança” de forma ampla, concluindo que, em relação às crianças privadas de liberdade, o Estado tem a obrigação de garantir assitência à saúde e à educação, para assegurar que a detenção, a qual estão sujeitas, não destrua seus projetos de

\footnotetext{
${ }^{63}$ Ao definir as "medidas de proteção" que devem ser proporcionadas às crianças à luz do art. 19 da Convenção Americana, a Corte transcreveu as disposições pertinentes da Convenção sobre os Direitos da Criança, destacando especificamente aquelas medidas necessárias para assegurar a "sobrevivência e o desenvolvimento" das crianças assim como o direito de toda criança a um nível de vida adequado para seu desenvolvimento físico, mental, espiritual, moral e social, particularmente nos aspectos da nutrição, vestimenta e moradia (Ibid. par. 196).

64 Ibid. par. 191.

${ }^{65}$ CORTE IDH. Caso "Instituto de Reeducación del Menor" vs. Paraguay. Excepciones Preliminares, Fondo, Reparaciones y Costas Sentença de 2 de setembro de 2004.

${ }^{66}$ Ibid. pars. 168- 172.
} 
vida $^{68}$. Ainda, a Corte citou as Regras das Nações Unidas para a Proteção dos Menores Privados de Liberdade que estabelecem que não se deve negar aos menores privados de liberdade, em razão de sua condição, os direitos civis, econômicos, sociais e culturais; e as Regras Mínimas das Nações Unidas para Administração da Justiça de Menores (Regras de Beijing) que dispõem que os menores privados de sua liberdade recebam os cuidados, proteção e toda assistência necessária - social, educacional, profissional, psicológica, médica e física ${ }^{69}$.

Com isso, a Corte especificou que o Estado violou o art. $4^{\circ}$ da Convenção Americana ao não prover a supervisão médica regular que assegure às crianças um desenvolvimento normal. Da mesma forma, determinou que o Estado violou este mesmo artigo por não oferecer, às crianças detidas, acesso a uma educação adequada. Esta obrigação, de acordo com a Corte, deriva tanto da “correta interpretação” do direito à vida quanto do art. 13 do Protocolo de San Salvador que consagra o direito à educação $^{70}$.

A jurisprudência relativa ao "projeto de vida” foi também estendida para aquelas populações vulneráveis, sem acesso aos bens básicos de subsistência. No caso Yakie Axa vs. Paraguai ${ }^{71}$, de 2005, em que a comunidade indígena, expulsa de seu território ancestral, vivia em uma situação terrível de desnutrição e empobrecimento, a Corte determinou que o Estado violou o direito à vida dos membros da comunidade por não aodtar medidas diante das condições que afetaram suas possibilidades de ter uma vida digna ${ }^{72}$. Uma das obrigações que deve assumir o Estado em sua

\footnotetext{
${ }^{67}$ Estabelecido pela Convenção sobre os Direitos das Crianças para monitorar este instrumento.

${ }^{68}$ CORTE IDH. Caso "Instituto de Reeducación del Menor" Vs. Paraguay, par. 161.

${ }^{69}$ As referências são em relação a regra 13 das Regras das Nações Unidas para a Proteção dos Menores Privados de Liberdade, adotadas pela Assembléia Geral em sua resolução 45/113 de 14 de dezembro de 1990; e a regra 26.2 das Regras Mínimas das Nações Unidas para Administração da Justiça de Menores adotadas pela Assembléia Geral em sua resolução 40/33 de 28 de novembro de 1985 (Ibid. pars. 161 e 163)

${ }^{70}$ Ibid. pars. 173- 174.

${ }^{71}$ CORTE IDH. Caso Comunidad Indígena Yakye Axa vs. Paraguay. Fondo Reparaciones y Costas. Sentença de 17 de junho de 2005.

${ }^{72}$ Ibid. par. 176.
} 
posição de garante ${ }^{73}$, afirmou a Corte, é de gerar condições de vida mínimas compatíveis com a dignidade da pessoa humana, com o objetivo de proteger e garantir o direito à vida ${ }^{74}$. A Corte, neste sentido, declarou que o Estado tem o dever de adotar medidas positivas, concretas e orientadas para a satisfação do direito a uma vida digna, especialmente quando se trata de pessoas em situação de vulnerabilidade e risco, cuja atenção se torna prioritária $^{75}$.

Com efeito, o direito à vida está estreitamente relacionado, neste caso, com os direitos econômicos, sociais e culturais, tais como o direito à saúde, à alimentação, água potável, educação e cultura. Nesta linha, a Corte buscou uma compreensão do direito à vida, à luz do corpus iuris internacional existente sobre a proteção especial que requerem os membros das comunidades indígenas, relacionando este direito com o dever geral de garantia do art. 1.1 da Convenção, com o dever de desenvolvimento progressivo contido no art. 26 da mesma, e com os arts. 10 (direito à saúde), 11 (direito a um meio ambiente sadio), 12 (direito à alimentação), 13 (direito à educação), 14 (direito aos benefícios da cultura) do Protocolo de San Salvador, e com as disposições pertinentes da Convenção N. 169 da $\mathrm{OIT}^{76}$

O direito à saúde foi amplamente desenvolvido pela Corte ao estabelecer que:

Las afectaciones especiales del derecho a la salud, e íntimamente vinculadas con él, las del derecho a la alimentación y el acceso al agua limpia impactan de manera aguda el derecho a una existencia digna y las condiciones básicas para el ejercicio de otros derechos humanos, como el derecho a la educación o el derecho a la identidad cultural. ${ }^{77}$

\footnotetext{
${ }^{73}$ Nas outras ocasiões em que a Corte se referiu à posição de garante do Estado estão relacionadas com pessoas privadas de liberdade, como nos casos Villagran Morales e Instituto de Reeducación del Menor.

${ }^{74}$ CORTE IDH. Caso Comunidad Indígena Yakye Axa vs. Paraguay. Fondo Reparaciones y Costas. Sentença de 17 de junho de 2005, par. 162.

${ }^{75}$ Ibid. par. 162.

${ }^{76}$ Ibid. par. 163 .

${ }^{77}$ Ibid. par. 167.
} 
Ainda, foi neste caso que a Corte, pela primeira vez, fez referência ao Comitê da ONU sobre os Direitos Econômicos Sociais e Culturais ${ }^{78}$, ao alegar a especial vulnerabilidade dos povos indígenas "cuyo acceso a las tierras ancestrales puede verse amenazado y, por lo tanto, su posibilidad de acceder a medios para obtener alimento y agua limpia" 79.

A decisão sobre o caso Comunidad Indígena Sawhoyamaxa vs. Paraguai $^{80}$, de 2006, seguiu esta mesma linha. No caso Yakie Axa vs. Paraguai, a Corte não considerou que a morte de dezesseis pessoas integrantes da comunidade fosse atribuída ao Estado, vez que não foi provada a existência de causalidade entre a falta de alimentação e atenção médica adequadas com as mortes. No caso Comunidade Indígena Sawhoyamaxa, por sua vez, a Corte, primeiramente, considerou provado o fato de um grupo de pessoas privadas de um amplo conjunto de direitos econômicos, sociais e culturais básicos, como o direito ao trabalho, à habitação adequada, à saúde, à água limpa ${ }^{81}$, - entre outros aspectos - gerou um risco para a vida destas pessoas resultando, efetivamente, na morte de alguns membros do grupo. Em segundo lugar, de acordo com a Corte, o fato do Estado ter tido conhecimento desta situação e ainda assim não ter proporcionado a devida assistência ou tê-la feito de forma insuficiente, era o mesmo responsável por descumprir a obrigação de garantir o direito à vida, em sua modalidade de prevenir violações deste direito. Este dever urge da conexão do art. 1.1 da Convenção com seu art. $4^{\text {o }}{ }^{82}$.

No caso Ximenes Lopez vs. Brasil ${ }^{83}$, de 2006, relacionado à morte de uma pessoa com deficiência mental que estava sob os cuidados de uma instituição psiquiátrica privada, a Corte desenvolveu pautas específicas sobre a responsabilidade de terceiros na prestação de serviços de saúde e na

\footnotetext{
${ }^{78}$ Estabelecido pela Resolução 1985/12, de 28 de maio de 1985, pelo Conselho Econômico e Social da ONU.

${ }^{79}$ CORTE IDH. Caso Comunidad Indígena Yakye Axa vs. Paraguay, par. 167.

${ }^{80}$ CORTE IDH. Caso Comunidad Indígena Sawhoyamaxa vs. Paraguay. Fondo, Reparaciones y Costas. Sentença de 29 de março de 2006.

${ }^{81}$ Ibid. par. 168.

${ }^{82}$ Ibid. pars. 159- 178.
} 
definição dos deveres do Estado em relação com as pessoas portadoras de deficiência mental. Asseverou, assim, que os Estados têm o dever de assegurar uma prestação médica eficaz às pessoas com este tipo de deficiência. O Tribunal esclareceu que essa obrigação se traduz no dever estatal de garantir seu acesso a serviços de saúde básicos; à promoção da saúde mental; à prestação de serviços dessa natureza, que sejam o menos restritivos possível; e à prevenção das deficiências mentais ${ }^{84}$.

Ainda assim, a Corte estabeleceu algumas diretrizes sobre a garantia da autonomia pessoal em relação ao exercício do direito à saúde. Declarou que o bem-estar do paciente portador de deficiência mental e sua dignidade devem acompanhar todo o seu tratamento. Os princípios orientadores do tratamento psiquiátrico seriam, então, o respeito à intimidade e à autonomia. Embora a Corte entenda que este último princípio não é absoluto, deve-se presumir que as pessoas portadoras deste tipo de deficiência são capazes de expressar sua vontade. Caso contrário, cumpre aos familiares, representantes legais ou autoridade competente emitir seu consentimento quanto ao tratamento a ser empregado ${ }^{85}$.

Outro importante aspecto, desenvolvido neste caso, relaciona-se com a obrigação, reiterada pela Corte, em garantir uma inspeção, vigilância e controle da prestação de serviço de saúde. Nestes termos, o Tribunal sustentou que estes deveres do Estado abrangem tanto as entidades públicas e privadas que prestam serviços públicos de saúde quanto aquelas instituições que prestam exclusivamente serviços privados de saúde ${ }^{86}$. Estas

\footnotetext{
${ }^{83}$ CORTE IDH. Caso Ximenes Lopes vs. Brasil. Fondo, Reparaciones y Costas. Sentença de 4 de julho de 2006.

${ }^{84}$ A Corte fez referência aos seguintes instrumentos internacionais: Princípios para a Proteção dos Doentes Mentais e para a Melhoria do Atendimento de Saúde Mental, Resolução da Assembléia Geral das Nações Unidas 46/119.46, p.189, ONU Documento A/46/49 (1991), princípio 1; Organização Mundial da Saúde. Divisão de Saúde Mental e Prevenção do Abuso de Substâncias. Dez Princípios Básicos das Normas para o Atendimento da Saúde Mental (1996), princípio 2; Normas Uniformes sobre Igualdade de Oportunidades para as Pessoas Portadoras de Deficiência. Resolução n ${ }^{\circ}$ 48/96 da Assembléia Geral da ONU, Documento A/48/49 (1993), art. 2; Declaração dos Direitos do Retardado Mental. Resolução da Assembléia Geral da ONU, Documento A/8429 (1971), art. 2; e Programa de Ação Mundial para os Impedidos. Resolução $\mathrm{n}^{\circ}$ 37/52 da Assembléia Geral da ONU, Documento A/37/51 (1982), par. 95 a 107 (Ibid. par. 128).

${ }^{85}$ Ibid. par. 130.

${ }^{86}$ Ibid. par. 141.
} 
considerações foram reiteradas, recentemente, no caso Albán Cornejo e outros vs. Equador ${ }^{87}$, de 2007, relacionado à má conduta médica. Segundo a Corte, o médico deve preservar os valores fundamentais do indivíduo e da humanidade em seu conjunto e que a legislação aplicável à má conduta dos médicos teria que satisfazer a devida realização da justiça no caso concreto $^{88}$.

Cumpre destacar que, nos casos relacionados com pessoas privadas de liberdade, a Corte interpretou, para efeitos de deteminar a responsabilidade estatal, tanto o alcance do direito à vida quanto da integridade pessoal, com o objetivo de avaliar as condições de detenção as quais incluem habitação, alimentação, saúde, acesso ao trabalho e educação, principalmente $^{89}$.

Portanto, a jurisprudência da Corte tem possibilitado que o direito à vida - e, em particular, o direito a uma vida digna ou projeto de vida - seja utilizado como eixo central para a projeção de diversos direitos econômicos, sociais e culturais no Sistema Interamericano.

\subsection{Direitos aos benefícios da cultura}

Um segundo avanço na jurisprudência da Corte, em matéria de direitos socioeconômicos e culturais, foi desenvolvido em relação às comunidades indígenas e ao acesso aos seus territórios ancestrais. Diversos casos sobre esta matéria foram submetidos à apreciação da Corte. O núcleo

\footnotetext{
${ }^{87}$ CORTE IDH. Caso Albán Cornejo y otros vs. Ecuador. Fondo Reparaciones y Costas. Sentença de 22 de novembro de 2007.

${ }^{88}$ Ibid. par. 133.

${ }^{89}$ Ver, neste sentido, CORTE IDH: Caso Caesar Vs. Trinidad y Tobago. Fondo, Reparaciones y Costas. Sentença 11 de março 2005; Corte IDH. Caso Fermín Ramírez Vs. Guatemala. Fondo, Reparaciones y Costas. Sentença de 20 de junho de 2005; Caso Gutiérrez Soler Vs. Colombia. Fondo, Reparaciones y Costas. Sentença de 12 de setembro de 2005; Caso De la Cruz Flores Vs. Perú. Fondo, Reparaciones y Costas. Sentença de 18 de novembro de 2004; Caso Tibi Vs. Ecuador. Excepciones Preliminares, Fondo, Reparaciones y Costas. Sentença de 7 de setembro de 2004; Caso Lori Berenson Mejía Vs. Perú. Fondo, Reparaciones y Costas. Sentença de 25 de novembro de 2004; Caso Hilaire, Constantine y Benjamin y otros Vs. Trinidad y Tobago. Fondo, Reparaciones y Costas. Sentença de 21 de junho de 2002; Caso Cantoral Benavides Vs. Perú. Fondo. Sentença de 18 de agosto de 2000; Caso Castillo Petruzzi y otros Vs. Perú. Fondo,
} 
central destes casos é composto pelos direitos à subsistência econômica, pela sobrevivência cultural e pela autodeterminação ${ }^{90}$. Tendo em vista a proteção destes direitos fundamentais, a Corte tem desenvolvido sua jurisprudência em relação aos arts. 21 (direito à propriedade) e 25 (proteção judicial) da Convenção Americana, além de considerar, adicionalmente, aspectos relativos ao direito a uma vida digna e ao projeto de vida, de acordo com o art. $4^{\circ}$ da Convenção Americana ${ }^{91}$.

Um dos casos de suma importância para a proteção dos direitos econômicos, sociais e culturais das comunidades indígenas foi o caso Comunidad Mayagna (Sumo) Awas Tingni vs. Nicarágua ${ }^{92}$, de 2001, referente à outorga, pelo governo da Nicarágua, de uma concessão a uma empresa estrangeira para explorar madeira em uma extensão de terra sem propriedade demarcada, a qual incluía o território ancestral da comunidade indígena Awas Tingni.

Neste caso, a Corte levou em consideração os valores, usos e costumes da Comunidade indígena Awas Tingni para elaborar sua sentença $^{93}$. O direito à propriedade foi aplicado pela Corte desde uma perspectiva coletiva dos povos indígenas e ligado indissoluvelmente tanto aos aspectos relacionados com o direito ao meio ambiente quanto ao exercício dos direitos culturais ${ }^{94}$.

Assim, ao aplicar as normas de interpretação do art. 29 da Convenção Americana, a Corte enfatizou que o art. 21 do mesmo instrumento protege o direito à propriedade que compreende, entre outros, os direitos dos membros das comunidades indígenas no marco da

\footnotetext{
Reparaciones y Costas. Sentença de 30 de maio de 1999; Caso Loayza Tamayo vs. Perú. Interpretación de la Sentencia de Reparaciones y Costas. Sentença de 3 de junho de 1999.

${ }^{90}$ MELISH, T. Op.cit. [II], p. 200.

${ }^{91}$ Ibid. p. 200.

${ }^{92}$ CORTE IDH. Caso de la Comunidad Mayagna (Sumo) Awas Tingni vs. Nicaragua. Fondo, Reparaciones y Costas. Sentença de 31 de agosto de 2001.

${ }^{93}$ Ibid. par. 164 e ponto resolutivo 3.

${ }^{94}$ Foi a partir da sentença sobre reparações no caso Aloeboetoe y otros vs. Suriname de 10 de setembro de 1993, no qual a Corte levou em consideração o direito cultural da tribo indígena cimarrones para efeitos de reparação, que foi considerada as particularidades culturais dos povos indígenas para determinar o modo pelo qual devem ser entendidos e resguardados seus direitos
} 
propriedade comunal $^{95}$. A importância multidimensional do território para a vida destes grupos - e, portanto, as obrigações especiais dos Estados para protegê-lo - foram claramente consideradas pela Corte. De acordo com o Tribunal, os indígenas, pelo fato de sua própria existência, têm o direito de viver livremente em seus próprios territórios; a estreita relação que os índios mantêm com a terra deve ser reconhecida e compreendida como a base fundamental de sua cultura, sua vida espiritual, sua integridade e sua sobrevivência econômica ${ }^{96}$. Salientou ainda que, para as comunidades indígenas, a relação com a terra não é apenas uma questão de posse ou produção, mas sim um elemento material e espiritual de que devem desfrutar plenamente, de modo a preservar seu legado cultural e trasmiti-lo às gerações futuras ${ }^{97}$. Fica claro, com estas afirmações da Corte, a estreita relação que se deu entre o direito à propriedade e os costumes e tradições indígenas, levando em especial consideração os direitos econômicos, sociais e culturais destes povos.

A Corte reconheceu também que o descumprimento do Estado em estabelecer um procedimento específico, efetivo e claro para a delimitação, demarção e emissão do título às terras da Comunidade Awas Tingni, de acordo com seu direito consentudinário, constituiu uma violação do art. 25 da Convenção, que consagra o direito à proteção judicial ${ }^{98}$.

Neste sentido, a Corte determinou que o Estado deveria adotar as medidas legislativas, administrativas e de qualquer outro caráter que fossem necessárias para criar um mecanismo efetivo de demarcação, delimitação e titulação das propriedades das comunidade indígenas, além de demarcar e titular as terras que correspondem aos membros das comunidade Awas Tingni, no prazo máximo de 15 meses, com a plena participação da comunidade. Para tanto, a Corte reiterou que o Estato deveria levar em

(CORTE IDH. Caso Aloeboetoe y otros Vs. Surinam. Reparaciones y Costas. Sentença de 10 de setembro de 1993.).

${ }^{95}$ CORTE IDH. Caso de la Comunidad Mayagna (Sumo) Awas Tingni vs. Nicarágua, par. 148.

${ }^{96}$ Ibid. par. 179.

${ }^{97}$ Ibid. par. 179.

${ }^{98}$ Ibid, pars. 138- 139. 
consideração os usos e costumes da comunidade ${ }^{99}$. Observa-se na sentença a importância de se considerar as tradições sociais e culturais da Comunidade para fins de reparação do dano por parte do Estado.

O caso Awas Tingni vs. Nicarágua trouxe oportunidades para outras reivindicações de comunidades indígenas, com a finalidade de retornarem às suas terras ancestrais, das quais foram retiradas por grupos mais poderosos. No caso já mencionado, Yakye Axa vs. Paraguai, de 2005, a comunidade indígena Yakye Axa, expulsa de sua terra ancestral, havia apresentado um pedido de devolução de seu território há mais de uma década. Privada do acesso às suas terras, a comunidade instalou-se nas proximidades de uma estrada, onde vivia em um estado de restrições alimentar, médica e sanitária, ameaçando constatemente a sobrevivência de seus membros e a integridade da comunidade. A Corte, neste caso, determinou que o Estado do Paraguai havia violado os arts. $4^{\circ}$ (direito à vida), 21 (direito à propriedade) e 25 (proteção judicial) da Convenção, reiterando a interrelação essencial entre o território ancestral, uma existência digna, e a proteção legal dos direitos de propriedade.

Recentemente, no caso do Pueblo Saramaka vs. Suriname ${ }^{100}$, de 2007, a Corte seguiu a mesma linha jurisprudencial relativa ao direito de propriedade dos povos indígenas, ao se referir aos povos tribais, dado que compartilham das mesmas características sociais, culturais e econômicas, como a relação especial com seus territórios ancestrais, o que requer medidas especiais, conforme o direito internacional dos direitos humanos $^{101}$. Importante assinalar que a Corte, nesta sentença, ao analisar a violação do art. 21 da Convenção, salientou que o Estado tem o dever de informar aos membros dos povos indígenas, ou tribais, sobre os riscos,

\footnotetext{
99 Ibid. par. 164.

100 Neste caso, o Estado não adotou medidas efetivas para reconhecer os direitos do pueblo Saramaka ao uso e gozo de seu território, ainda não lhes garantiu efetivo acesso à justiça para a proteção de seus direitos fundamentais, particularmente o direito a possuir propriedade de acordo com suas tradições (CORTE IDH. Caso del Pueblo Saramaka. vs. Surinam. Excepción Preliminar, Fondo, Reparaciones y Costas. Sentença de 28 de novembro de 2007.).

101 Ibid. par. 86.
} 
incluindo os riscos ambientais e à saúde, que resultarem de planos de desenvolvimento propostos em seus territórios. Neste sentido, declarou que:

[...]cuando se trate de planes de desarrollo o de inversión a gran escala que tendrían un mayor impacto dentro del territorio Saramaka, el Estado tiene la obligación, no sólo de consultar a los Saramakas, sino también debe obtener el consentimiento libre, informado y previo de éstos, según sus costumbres y tradiciones. ${ }^{102}$

Além disso, acrescentou que o art. 21 da Convenção não proíbe per se a autorização de concessões para exploração dos recursos naturais em territórios indígenas ou tribais. Todavia, se o Estado pretender restringir, legitimamente, os direitos à propriedade comunal deve realizar previamente estudos de impacto ambiental e social ${ }^{103}$.

Portanto, as decisões da Corte têm sido baseadas no reconhecimento da relação especial que esses povos têm com seu território, e com a necessidade de proteger seu direito àquele território para garantir sua sobrevivência econômica, social e cultural, no que se refere as violações do direito à propriedade que protege o direito dos membros dos povos indígenas ou tribais ao uso e gozo da propriedade comunal ${ }^{104}$.

\subsection{Direitos sindicais}

O Sistema Interamericano também avançou na jurisprudência dos direitos dos trabalhadores à livre formação de sindicatos, sem a intervenção de agentes governamentais ou privados. A Corte teve a oportunidade de examinar amplamente as dimensões dos direitos sindicais, consagrados no art. 8 do Protocolo de San Salvador, em sua sentença no caso Baena Ricardo e outros vs. Panamá ${ }^{105}$. No caso em pauta, por meio de uma lei retroativa (Lei 25), foram arbitrariamente destituídos de seus cargos 270

\footnotetext{
102 Ibid. par. 134.

103 Ibid. par. 143.

${ }^{104}$ Neste sentido, além dos casos citados, podem-se mencionar os seguintes: CORTE IDH. Caso Masacre Plan de Sánchez vs. Guatemala. Reparaciones y Costas. Sentença de 19 de noviembre de 2004, par. 85; Caso Comunidad Indígena Sawhoyamaxa vs. Paraguay. Fondo, Reparaciones y Costas. Sentença de 29 de março de 2006, par. 118.
} 
empregados públicos que haviam participado de uma manifestação por reclamações trabalhistas, sendo acusados de cumplicidade com um golpe militar. A sentença da Corte, em relação a este caso, pode ser considerada paradigmática, porque, pela primeira vez, foi abordado um tema com efeitos trabalhistas e sindicais, abrindo novas oportunidades dentro do Sistema Interamericano para a reivindicação dos direitos dos trabalhadores nas Américas.

A Corte reiterou, em suas considerações preliminares, sua competência para aplicar tratados de direitos humanos distintos da Convenção Americana ${ }^{106}$. Reafirmou ainda o princípio de Direito Internacional geral pelo qual os Estados têm o dever de cumprir de boa-fé (pacta sunt servanda) os instrumentos internacionais por eles ratificados, consagrado na Convenção de Viena sobre o Direito dos Tratados (1969) ${ }^{107}$. A Corte deixou claro, assim, que quando um Estado ratifica o Protocolo de San Salvador, deve abster-se de realizar qualquer ato contrário ao objeto e fim do mesmo, ainda que antes de sua entrada em vigor ${ }^{108}$.

Nesta sentença, a Corte realizou apreciações sobre aspectos relacionados aos direitos trabalhistas e à livre associação em matéria sindical. A Corte não pôde aplicar diretamente o art. 8 do Protocolo de San Salvador, que protege o direito dos trabalhadores de se organizar e se afiliar a sindicatos, já que na época em que ocorreram os fatos, o Estado do Panamá não era signatário deste instrumento. Contudo, utilizou-se do mesmo para interpretar os alcances do art. 16 da Convenção Americana que trata da liberdade de associação.

Em primeiro lugar, o Tribunal afirmou que sob qualquer circunstância em que se imponha uma sanção administrativa a um(a) trabalhador(a), deve resguarda-se o devido processo legal, e também sustentou que as demissões tiveram graves conseqüências socioeconômicas

\footnotetext{
${ }^{105}$ CORTE IDH. Caso Baena Ricardo y otros Vs. Panamá. Fondo, Reparaciones y Costas. Sentença de 2 de fevereiro de 2001.

${ }^{106}$ Ibid. par. 97.

${ }^{107}$ Ibid. par. 98.
} 
para as pessoas demitidas e para seus familiares e dependentes, tais como a diminuição da renda e do padrão de vida.

Em matéria sindical, a Corte fez um estudo detalhado dos direitos sindicais, consagrados no artigo 8 do referido Protocolo. Com efeito, examinou a liberdade de associação em relação à liberdade sindical e, para isso, citou instrumentos da OIT e resoluções desta organização concernentes à proteção de direitos sociais. A Corte assinalou que a liberdade de associação, em matéria sindical, consiste basicamente na faculdade de constituir organizações sindicais e colocar, em prática, sua estrutura interna, atividades e programas de ação, sem intervenção das autoridades públicas que limitem ou dificultem o exercício do respectivo direito. Por outro lado, essa liberdade supõe que cada pessoa possa determinar, sem coação alguma, se deseja ou não formar parte da associação, já que se trata do direito fundamental de agrupar-se para a realização comum de um fim lícito, sem pressões ou intromissões que possam alterar sua finalidade ${ }^{109}$.

A Corte fez referência ao preâmbulo da Constituição da OIT que reconhece que a liberdade de associação em matéria sindical "reviste la mayor importancia para la defensa de los intereses legítimos de los trabajadores y se enmarca en el corpus juris de los derechos humanos”110. Nesta esteira, a liberdade de associação, em matéria trabalhista, nos termos do art. 16 da Convenção Americana, compreende tanto um direito quanto uma liberdade, a saber: o direito de associar-se livremente sem restrições, com exceção daquelas previstas nos incisos 2 e 3, do referido artigo, e a liberdade de toda pessoa de não ser obrigada a associar-se. O Protocolo de San Salvador, em seu art. 8.3, reconhece os mesmos preceitos e prevê ainda que, em matéria sindical, “ninguém poderá ser obrigado a pertencer a um sindicato" ${ }^{\prime 11}$.

\footnotetext{
${ }^{108}$ Ibid. par. 99

${ }^{109}$ Ibid. pars. 156, 157, 158, 162, 164 e 171.

${ }^{110}$ Ibid. par. 158.

${ }^{111}$ Ibid. par. 159.
} 
A Corte estabeleceu que, no caso em questão, ao demitir os trabalhadores estatais, foram demitidos também dirigentes sindicais que estavam envolvidos em uma série de reivindicações; ademais, os sindicalistas foram demitidos por atos que não constituíam causas de demissão na legislação vigente no momento dos fatos. De acordo com o Tribunal, ficou demonstrado que, ao atribuir efeito retroativo à Lei 25, seguindo as ordens do Poder Executivo, pretendeu-se dar fundamento à demissão massiva de dirigentes sindicais e trabalhadores do setor público, atuação que limita as possibilidades de ação das organizações sindicais no mencionado setor ${ }^{112}$.

Neste sentido, a Corte estimou que a Convenção Americana fosse clara ao assinalar, em seu art. 16, que a liberdade de associação só pode estar sujeita às restrições previstas em lei e que se façam necessárias, em uma sociedade democrática, ao interesse da segurança nacional, da ordem pública, ou para proteger a saúde ou a moral pública ou os direitos e as liberdades das demais pessoas. Esta previsão encontra-se também consagrada no art. 8 do Protocolo de San Salvador. Neste sentido, a Convenção Americana não se limita a exigir a existência de uma lei para que sejam juridicamente lícitas as restrições ao gozo e exercício dos direitos e liberdades, mas requer que tal lei seja elaborada por razões de interesse geral e com o propósito pelo qual foi estabelecida, conforme esclareceu a Corte $^{113}$.

Em sua resolução sobre o caso, a Corte concluiu - entre outros aspectos - que o Estado violou o direito à liberdade de associação e ordenou a reintegração dos trabalhadores a seus postos de trabalho ou, se isto não fosse possível, o Estado deveria oferecê-los alternativas de empregos que respeitassem as condições, os salários e remunerações que tinham no momento em que foram demitidos ${ }^{114}$. Tão importante quanto a violação direta do direito à liberdade de associação foi a determinação pela Corte da

\footnotetext{
112 Ibid. par. 160.

113 Ibid. pars. 168 e 170.

${ }^{114}$ Ibid. pars. 160, 166 e 172, e ponto resolutivo N 7.
} 
violação dos arts. 8, 9 e 25 da Convenção Americana, demonstrando a importância das proteções processuais para a proteção efetiva dos direitos econômicos, sociais e culturais ${ }^{115}$.

Essa sentença analisada deixa entrever uma certa preocupação da Corte pelos direitos sociais e econômicos dos trabalhadores (como o direito à um nivel de vida adequado e o direito ao trabalho). Isto fica evidenciado no momento das reparações em que a Corte exigiu que o Estado adotasse medidas de cunho social e econômicos. Deve-se ressaltar, no entanto, que essa proteção foi estabelecida através do reconhecimento de violações aos direitos civis e políticos.

No caso Huilca Tecse vs. Peru, de $2005^{116}$, a Corte ampliou seu entendimento sobre os direitos sindicais. Neste caso, o Estado do Peru reconheceu sua responsabilidade internacional em relação às violações do direito à vida e à liberdade de associação, consagrados nos arts. $4^{\circ}$ e 16 da Convenção, respectivamente, pela execução extrajudicial de Pedro Huilca, importante líder sindical peruano dos anos noventa ${ }^{117}$. Contudo, a Corte fez algumas declarações acerca do alcance e importância do direito da liberdade de associação em relação com as dimensões individuais e coletivas da liberdade sindical.

A Corte considerou que esta execução, dentro do contexto de violência sócio-político que ocorria na época dos fatos, restringia tanto a liberdade de associação de um indivíduo quanto o direito à liberdade de determinado grupo a associar-se livremente, sem medo ou temor. A Corte, então, declarou que o art. 16 da Convenção tem duas dimensões ${ }^{118}$, a saber: a individual e a coletiva ou social.

Neste sentido, considerou-se que o Estado violou o art. 16 da Convenção, em sua dimensão individual, vez que a execução extrajudicial restringia o seu direito de utilizar todos os meios apropriados para exercer

\footnotetext{
${ }^{115}$ MELISH, T. Op.cit. [II], p. 204.

${ }^{116}$ CORTE IDH. Caso Huilca Tecse vs. Perú. Fondo, Reparaciones y Costas. Sentença de 03 março de 2005.

${ }^{117}$ Ibid. par. 20.
} 
sua liberdade e de alcançar, coletivamente, os fins lícitos pelos quais eram direcionadas suas ações ${ }^{119}$. Ademais, a execução teve o efeito de limitar a atuação dos trabalhadores do movimento sindical peruano e, com isso, restringia a liberdade de um grupo determinado a exercer o seu direito à liberdade de associação ${ }^{120}$. Assim, a execução violou a dimensão social do direito à liberdade de associação, já que o direito da coletividade de atingir os fins que perseguia sofreu uma restrição. Com isso, a Corte acrescentou que:

El Estado debe garantizar que las personas puedan ejercer libremente su libertad sindical sin temor de que serán sujetos a violencia alguna, de lo contrario, se podría disminuir la capacidad de las agrupaciones de organizarse para la protección de sus intereses. ${ }^{121}$

A Corte estabeleceu, portanto, que as duas dimensões mencionadas do direito à liberdade de associação devem ser garantidas simultanaemente, sem prejuízo daquelas restrições permitidas no inciso 2 do art. 16 da Convenção $^{122}$. Cumpre ressaltar, por fim, que assim como no caso Baena Ricardo, a Corte se referiu ao Protocolo de San Salvador e a Convenção $\mathrm{OIT}^{123}$, para ampliar a interpretação do direito à liberdade de associação ${ }^{124}$.

Posteriormente, no caso Cantoral Huamaní y García Santa Cruz vs. $\operatorname{Peru}^{125}$ (2007), a Corte reiterou que o direito à liberdade sindical, incluído

\footnotetext{
${ }^{118}$ Ibid. par. 69.

${ }^{119}$ Neste sentido, a Corte declarou que: “[e]n su dimensión individual, la libertad de asociación, en materia laboral, no se agota con el reconocimiento teórico del derecho a formar sindicatos, sino que comprende además, inseparablemente, el derecho a utilizar cualquier medio apropiado para ejercer esa libertad” ( Ibid. par. 70).

${ }^{120}$ Ibid. par. 78.

${ }^{121}$ Ibid. par. 77.

${ }^{122} \mathrm{O}$ inciso 2 do art. 16 da Convenção Americana dispõe que: O exercício desse direito só pode estar sujeito às restrições previstas em lei e que se façam necessárias, em uma sociedade democrática, ao interesse da segurança nacional, da segurança e da ordem públicas, ou para proteger a saúde ou a moral públicas ou os direitos e as liberdades das demais pessoas.

${ }^{123}$ Convenção No. 87 da OIT relativa a Liberdade Sindical e a Proteção do Direito de Sindicalização de 17 de junho de 1948.

${ }^{124}$ Neste sentido, Corte: "[l]a Corte recuerda lo señalado en el Protocolo de San Salvador de 17 de noviembre de 1988 y en el Convenio No. 87 de la OIT relativo a la Libertad Sindical y a la Protección del Derecho de Sindicación de 17 de junio de 1948, los cuales en sus artículos 8.1.a y 11, respectivamente, comprenden la obligación del Estado de permitir que los sindicatos, federaciones y confederaciones funcionen libremente" (Corte IDH. Caso Huilca Tecse Vs. Perú, par. 74).

${ }^{125}$ CORTE IDH. Caso Cantoral Huamaní y García Santa Cruz vs. Perú. Excepción Preliminar, Fondo, Reparaciones y Costas. Sentença de 10 de julho de 2007.
} 
no exercício da liberdade de associação, é afetado nos casos em que as violações do direito à integridade pessoal ou à vida impeçam sua consagração. A violação deste direito não atinge apenas a vítima individual, mas abarca também a coletividade que exerce esse direito. Logo, a Corte assinalou que "los derechos sindicales no pueden ser ejercidos en un contexto de impunidad frente a situaciones de violencia sindical caracterizadas, inter alia, por ejecuciones extrajudiciales”. Neste sentido, ressaltou a importância do Estado de investigar com a devida diligência e efetivamente os crimes contra dirigentes sindicais, considerando que a falta de investigações tem o efeito de coibir o livre exercício dos direitos sindicais, já que cria uma situação de medo e insegurança ${ }^{126}$.

Nos casos analisados, é notório que a Corte realizou uma interpretação da liberdade de associação consagrado na Convenção, focada principalmente na proteção dos direitos sindicais dos trabalhadores. Fica claro, desta forma, que apesar da possibilidade de alegar violação direta do direitos sindicais consagrados no art. 13 do Protocolo de San Salvador, a Corte prefere utilizar este instrumento indiretamente para estabelecer violações de direitos civis e políticos.

\subsection{Direito à previdência social}

O caso mais relevante da Corte em matéria de previdência social foi o caso "Cinco Pensionistas" vs. Peru ${ }^{127}$, de 2001. A Corte, neste caso, decidiu em favor de cinco pensionistas cujas pensões foram reduzidas pelo Estado de acordo com o Decreto-Lei de 1992. A Corte teve por referência à Constituição peruana e às decisões judiciais da jurisdição interna, declarando, unanimemente, que o direito adquirido à pensão dos cincos pensionistas foi violado de acordo com as garantias constitucionais do Peru.

\footnotetext{
${ }^{126}$ Ibid. pars. 145- 148.

${ }^{127}$ CORTE IDH. Caso "Cinco Pensionistas" vs. Perú. Fondo, Reparaciones y Costas. Sentença de 28 de fevereiro de 2003.
} 
Seguindo esta determinação, a Corte considerou que o Estado do Peru era responsável pelas violações do direito à propriedade privada e ao direito à proteção judicial, consagrados nos art. 21 e 25 da Convenção Americana, respectivamente. Desta forma, o direito à previdência social, neste caso, se vincula aos direitos da Convenção supracitados, já que o recebimento de uma pensão de aposentadoria representa um direito que foi incorporado ao patrimônio das pessoas e, no caso concreto, houve uma redução ilegal destas pensões, de aproximadamente $78 \%$, afetando os recursos econômicos dos pensionistas. Com isso, sustentou a Corte, que as vítimas adquiriram um direito de propriedade sobre os efeitos patrimoniais do seu direito à pensão ${ }^{128}$.

A Corte observou, em seguida, que não obstante os Estados possam impor limitações ao gozo do direito à propriedade por razões de utilidade pública ou interesse social, no caso dos efeitos patrimoniais das pensões, os Estados somente podem reduzi-los por via legal adequada ou por outros motivos que foram devidamente indicados na sentença. Assinalou, em suas considerações, que o art. $5^{\circ}$ do Protocolo de San Salvador apenas permite aos Estados estabelecer restrições e limitações ao gozo e exercício dos direitos estabelecidos no referido instrumento mediante leis promulgadas com o objetivo de preservar o bem estar geral dentro de uma sociedade democrática, na medida em que não contrariem o propósito e razão dos mesmos $^{129}$. Adicionou que em toda e qualquer circunstância, se a restrição ou limitação afeta o direito à propriedade, esta deve realizar-se, em conformidade com os parâmetros estabelecidos no art. 21 da Convenção Americana $^{130}$.

\footnotetext{
${ }^{128}$ A Corte definiu "bens" como: aquellas cosas materiales apropiables, así como todo derecho que pueda formar parte del patrimonio de una persona; dicho concepto comprende todos los muebles e inmuebles, los elementos corporales e incorporales y cualquier otro objeto inmaterial susceptible de valor (CORTE IDH. Caso Ivcher Bronstein vs. Peru. Sentença de 6 de fevereiro de 2001, par. 122).

${ }^{129}$ CORTE IDH. Caso "Cinco Pensionistas" vs. Perú, par. 116.

130 Estes "parâmetros” que a Corte se refere estão estabelecidos no próprio art. 21 da Convenção Americana que prevê: 1 . Toda pessoa tem direito ao uso e gozo de seus bens. A lei pode subordinar esse uso e gozo ao interesse social; 2. Nenhuma pessoa pode ser privada de seus bens, salvo mediante o pagamento de indenização justa, por motivo de utilidade pública ou de interesse
} 
Assim, a Corte constatou que o Estado ao mudar arbitrariamente o montante das pensões que as vítimas vinham recebendo e ao não cumprir com as sentenças judiciais emitidas a favor das mesmas, violou o direito à propriedade, consagrado na Convenção Americana ${ }^{131}$. O direito à proteção judicial, por sua vez, foi considerado violado pela Corte, devido a demora no caso, oito anos - do Estado em executar as sentenças emitidas pela Corte Suprema de Justiça do Peru ${ }^{132}$.

Cabe mencionar que, segundo a Corte, os fatos ocorridos no caso em apreço causaram danos aos pensionistas que tiveram sua "qualidade de vida”133 atingida com a redução arbitrária das pensões e com a falta de cumprimento das sentenças emitidas a seu favor. Por estas razões, a Corte determinou que “el daño inmaterial ocasionado debe además ser reparado, por vía sustitutiva, mediante una indemnización compensatoria, conforme a la equidad"134.

É interessante notar nesta sentença a argumentação que a Corte realiza em relação ao direito à propriedade. Embora, como nos outros casos, adote a prática tradicional de analisar sua violação dentro de aspectos dos direitos civis e políticos, se vale do art. $5^{\circ}$ do Protocolo para explicar as limitações as quais pode ser submetido este direito. Neste sentido, é inegável que a Corte equipara o direito à propriedade a um direito de aspectos econômicos e sociais.

Os casos apresentados no presente capítulo deixam clara a prática jurisprudencial da Corte em se concentrar na análise de violações dos

social, nos casos e na forma estabelecidos pela lei; 3 . Tanto a usura, como qualquer outra forma de exploração do homem pelo homem, devem ser reprimidas pela lei.

${ }^{131}$ CORTE IDH. Caso "Cinco Pensionistas" vs. Peru, par. 121.

132 Ibid. par. 141.

133 O termo "qualidade de vida" é considerado denominador comum dos direitos econômicos, sociais e culturais. "Para la consideración de los derechos económicos, sociales y culturales es muy importante el concepto del nivel de vida, el cual es el comun denominador de estos derechos, ya que es precisamente al medir el nivel de vida de los habitantes de un país que se obtiene como resultado el nivel de desarrollo o subdesarrolo, en su defecto, de este. Tradicionalmente, los indicadores socioeconômicos para evaluar el nivel de vida son: salud, alimentación, educación, condiciones de trabajo, situación ocupacional, vivienda, descanso, esparciamiento y seguridad social, entre otros, los cuales a su vez se constituyen em derechos económicos, sociales $y$ culturales” (ROBLES, M. Op.cit., p. 90).

${ }^{134}$ CORTE IDH. Caso "Cinco Pensionistas" vs. Peru, par. 180. 
direitos civis e políticos, considerando-os cada vez mais dentro de seus aspectos econômicos, sociais e culturais. Em determinados casos o grau dessa proteção é tão forte que a Corte parece tratar mais de um DESC do que de um direito civil e político, como no caso do direito à saúde.

Embora esta prática jurisprudencial não seja necessariamente problemática, dado a indivisibilidade e interdependência inerentes a todos os direitos, não é a mais ideal, vez que obscurece as dimensões essenciais dos direitos tradicionalmente pensados como "econômicos, sociais e culturais.” Como bem apontou Tara Melish, o direito à saúde, por exemplo, tem dimensões particulares que não podem ser alcançadas nem abordadas através da análise ampla do direito à vida, incluindo a acessibilidade aos serviços de saúde, à qualidade de bens e serviços. O mesmo ocorre com o direito à educação, que vai muito além do estritamente necessário para o desenvolvimento da criança ou para assegurar o seu “projeto de vida”. Inclui também a alfabetização de adultos, acesso a materiais escolares, professores qualificados, etc., ou seja, muitos elementos que vão além do direito à vida ${ }^{135}$.

É fundamental considerar os direitos civis e políticos em suas dimensões sociais, culturais e econômicas, principalmente naqueles casos em que as condições necessárias para alcançar uma existência digna estão ausentes e considerar violações específicas é impossível. Como metodologia, no entanto, esta prática é inadequada para tratar o grande volume de demandas que surge cada vez mais no continente americano demandas que já chegam à Comissão Interamericana e que logo chegarão à Corte.

Além disso, a ênfase excessiva da Corte em relação aos direitos do capítulo II da Convenção pode acarretar em uma debilidade das normas. Considerados de uma forma muito abrangente, estes direitos acabam perdendo sua especificidade. Segundo Tara Melish, a "falta de claridad puede amenazar la legitimidad y predictibilidad del Sistema, produciendo

\footnotetext{
${ }^{135}$ MELISH, T. Op.cit. [II], p. 215- 216.
} 
consecuencias negativas en la protección sostenible de los derechos humanos a largo plazo"136. Isto ocorre, notoriamente, com os arts. $4^{\mathrm{o}}$ e $5^{\mathrm{o}} \mathrm{da}$ Convenção. Como visto, o direito à vida foi interpretado de forma a incluir os direitos à saúde, à educação, à água, à habitação e outros direitos necessários a uma vida digna. Da mesma forma, a Corte incorporou no art. 19 da Convenção todos os direitos econômicos, sociais e culturais definidos na Convenção sobre os Direitos da Criança. Embora esta interpretação ampla tenha possibilitado às vitimas a proteção dos direitos sociais, ela não é necessariamente boa, vez que acaba perdendo de vista quais os direitos que estão sendo realmente protegidos.

${ }^{136}$ Ibid. p. 216. 


\section{CAPÍTULO III}

\section{A APLICAÇÃO DO ART. 26 DA CONVENÇÃO AMERICANA NA JURISPRUDÊNCIA DA CORTE INTERAMERICANA DE DIREITOS HUMANOS}

A Corte tem tido enormes dificuldades para estabelecer sua jurisprudência sobre a aplicação do art. 26 que, conforme já exposto anteriormente, é o único artigo sobre direitos econômicos, sociais e culturais previsto na Convenção Americana ${ }^{137}$. Com efeito, tem evitado a proteção autônoma destes direitos em sua prática jurisprudencial. Esta tendência pode ser verificada pela análise de alguns casos em que teve que se pronunciar acerca do referido artigo.

Foi, pela primeira vez, no caso Cinco Pensionistas vs. Peru, que a Comissão Interamericana de Direitos Humanos solicitou à Corte que declarasse a violação do art. 26 da Convenção por parte do Estado do Peru. Cumpre assinalar que a Comissão alegou o seu descumprimento, sustentando que o Estado, ao reduzir arbitrariamente o montante das pensões de aposentadoria das vítimas, não cumpriu com seu dever de promover o desenvolvimento progressivo de seus direitos econômicos, sociais e culturais e, particularmente, não lhes garantiu o desenvolvimento progressivo do direito à previdência social ${ }^{138}$. Nota-se que os peticionários não optaram por alegar a violação autônoma do direito à pensão das cinco vítimas dentro do art. 26 da Convenção, mas pela alegação de que este artigo foi violado pelo descumprimento do “deber de dar el desarrollo progresivo de sus DESC, particularmente de su derecho a la pensión.”139 (grifou-se).

Com base neste argumento a Corte apontou que:

\footnotetext{
${ }^{137}$ A Comissão Interamericana de Direitos Humanos, por sua vez, apesar das dificuldades em estabelecer o conteúdo e alcance do art. 26, já reconheceu em alguns casos individuais a violação do mesmo. No caso, Jorge Odir Miranda Cortéz, a Comissão considerou que o direito à saúde encontra-se protegido na Convenção Americana pelo referido artigo e que por esta via está facultada para considerar violações a este direito em casos individuais (Cf. CIDH. Informe $\mathrm{N}^{\circ}$. 29/01, Caso 12.249, Jorge Odir Miranda Cortéz, El Salvador, 7 mar. 2001).

${ }_{138}$ CORTE IDH. Caso "Cinco Pensionistas" vs. Peru, par. 142.

${ }^{139}$ MELISH, T. Op.cit. [II], p. 207.
} 
Os direitos econômicos, sociais e culturais têm uma dimensão tanto individual quanto coletiva. Seu desenvolvimento progressivo, sobre o qual já se pronunciou o Comitê de Direitos Econômicos, Sociais e Culturais das Nações Unidas ${ }^{140}$, deve-se medir, pelo critério deste Tribunal, em função da crescente cobertura dos direitos econômicos, sociais e culturais em geral, e do direito à previdência social e à pensão em particular, sobre o conjunto da população, levando em conta os imperativos da equidade social, e não em função das circusntâncias de um grupo muito limitado de pensionistas não necessariamente representativos da situação geral prevalecente." 141

Assim a Corte considerou que o caso em questão tratava de um grupo muito limitado de pensionistas (cinco) que não eram, necessariamente, representativos da situação geral prevalecente. Por tais motivos, decidiu não se manifestar acerca do desenvolvimento progressivo $^{142}$ dos direitos econômicos, sociais e culturais ${ }^{143}$. Lamentavelmente, esta decisão limitou consideravelmente o alcance dos direitos individuais no marco do art. 26 da Convenção, e assim destacou o juiz Sergio García Ramírez em seu voto separado. Referindo-se a manifestação explícita feita pela Corte de que os direitos econômicos, sociais e culturais têm uma dimensão tanto individual quanto coletiva, García Ramírez entendeu que esta dimensão individual se traduz em uma titularidade do mesmo modo individual: de interesse jurídico e de um direito correpondente que pode ser compartilhado com outros membros de uma população ou de um setor desta. O juiz recordou que a Convenção constitui, precisamente, uma normativa sobre direitos humanos e não um mero catálogo de obrigações gerais do Estado. Em consequência, a

\footnotetext{
${ }^{140}$ Comitê dos Direitos Econômicos, Sociais e Culturais da ONU. Observação Geral No. 3: A índole das obrigações dos Estados partes (art. 2, par. 1 do Pacto), U.N. Doc. E/1991/23, adotada no Quinto Período de Sessões, 1990, ponto 9.

${ }^{141}$ Tradução livre do espanhol: "Los derechos económicos, sociales y culturales tienen una dimensión tanto individual como colectiva. Su desarrollo progresivo, sobre el cual ya se ha pronunciado el Comité de Derechos Económicos, Sociales y Culturales de las Naciones Unidas, se debe medir, en el criterio de este Tribunal, en función de la creciente cobertura de los derechos económicos, sociales y culturales en general, y del derecho a la seguridad social y a la pensión en particular, sobre el conjunto de la población, teniendo presentes los imperativos de la equidad social, y no en función de las circunstancias de un muy limitado grupo de pensionistas no necesariamente representativos de la situación general prevaleciente" (CORTE IDH. Caso "Cinco Pensionistas" vs. Perú, par. 147).

${ }^{142}$ Sobre a noção de progressividade e de não regressividade do art. 26 da Convenção, ver o voto do juiz Rodolfo E. Piza Escalante, em: CORTE IDH. Opinión Consultiva OC-4/84, pars. 6 e 31.

${ }^{143}$ CORTE IDH. Caso "Cinco Pensionistas" vs. Peru, par. 148.
} 
existência de uma dimensão individual dos direitos humanos sustenta a denominada “justiciabilidade” dos mesmos, que tem avançado no plano nacional e tem um amplo horizonte no plano internacional ${ }^{144}$.

O juiz Roux Rengifo, por sua vez, considerou que a idéia sustentada pela Corte, segundo a qual só seria procedente submeter ao art. 26 as violações cometidas pelos Estados que afetem o conjunto da população, não parece ter sustentação na Convenção, entre outras razões, porque a Corte Interamericana não pode exercer - diferente do que ocorre com a Comissão Interamericana - uma atividade geral de monitoramento sobre a situação dos direitos humanos, sejam civis e políticos ou econômicos, sociais e culturais. O Tribunal só pode atuar diante dos casos de violação aos direitos humanos de pesssoas determinadas, sem que a Convenção exija que estas devam alcançar um determinado número ${ }^{145}$. Neste sentido, a própria Corte já entendeu que sua jurisdição contenciosa se exerce com a finalidade de proteger os direitos e liberdade de pessoas determinadas e não de resolver casos em abstrato ${ }^{146}$.

Em relação com a progressividade dos direitos econômicos, sociais e culturais, a qual se referiu a sentença da Corte ao medi-la em função da “crescente cobertura dos direitos econômicos, sociais e culturias em geral, e do direito à previdência social e à pensão em particular, sobre o conjunto da população, levando em conta os imperativos de equidade social”, o juiz García Ramírez precisou que “con sustento en esa ponderación el Tribunal apreciará el cumplimiento del deber estatal y la existencia del derecho individual, y podrá resolver el litigio específico que tenga a la vista”147.

\footnotetext{
${ }^{144}$ CORTE IDH. Caso "Cinco Pensionistas" vs. Peru, voto concurrente razonado del juez Sergio García Ramírez. Estas considerações receberam respaldo na doutrina de Héctor Faúndez Ledesma que anunciou expressamente compartilhar da mesma opinião (LEDESMA, H. Op.cit., p. 116117).

${ }^{145}$ CORTE IDH. Caso "Cinco Pensionistas" vs. Peru, voto razonado del juez de Roux Rengifo. Sentença de 28 de fevereiro de 2003.

${ }^{146}$ CORTE IDH. Opinión Consultiva OC-14/94. Responsabilidad Internacional por Expedición y Aplicación de Leyes Violatorias de la Convención (arts. 1 y 2, Convención Americana sobre Derechos Humanos). 9 dez 1994, par. 49.

${ }_{147}$ CORTE IDH. Caso "Cinco Pensionistas" vs. Peru, voto concurrente razonado del juez Sergio García Ramírez.
} 
Em casos posteriores, a jurisprudência da Corte não apresentou qualquer avanço no que tange a interpretação do art. 26. Neste sentido, no caso Instituto de Reeducación del Menor vs. Paraguai, de 2004, a Corte analisou a alegação dos representantes das vítimas, segundo a qual o art. 26 não era observado pelo Estado que descumpriu com sua obrigação de garantir os níveis mínimos de satisfação dos direitos econômicos sociais e culturais $^{148}$. Tendo em vista as considerações referentes aos aspectos de uma vida digna, da saúde, educação e recreação com relação à análise das violações dos arts. $4^{\circ}$ e $5^{\circ}$ da Convenção, em relação ao art. 19 da mesma e com o art. 13 do Protocolo de San Salvador, a Corte considerou que não era necessário pronunciar-se a respeito do art. 26 da Convenção ${ }^{149}$.

Por outro lado, no caso da Comunidad Indígena Yakye Axa vs. Paraguai, a Corte utilizou o art. 26 da Convenção Americana em sua análise, referente à violação do direito à vida, junto com disposições do Protocolo de San Salvador e da Convenção 169 da OIT. Considerou que a obrigação de "generar las condiciones de vida mínimas compatibles con la dignidad de la persona humana”, deveria, no caso concreto, ser levada em conta com a obrigação de desenvolvimento progressivo prevista no art. 26 da Convenção Americana e com alguns direitos previstos no Protocolo de San Salvador ${ }^{150}$. Embora a Corte não tenha mencionado o art. 26 na parte resolutiva da sentença, a consideração da vigência dos direitos econômicos, sociais e culturais e sua conexão com o direito a uma vida digna gerou um precedente de proteção de suma importância.

\footnotetext{
${ }^{148}$ Os representantes das vítimas alegaram que o art. 26 da convenção Americana deveria ser estudado em conexão com o art. 19 da mesma e com os arts. XI, XII, XIII, XV da Declaração Americana de Direitos Humanos e com os arts. 24, 28, 29 e 31 da Convenção sobre o Direito das Crianças (CORTE IDH. Caso "Instituto de Reeducación del Menor" vs. Paraguay. Sentença de 2 de setembro de 2004, par. 253).

${ }^{149}$ Os representantes das vítimas alegaram que o art. 26 da convenção Americana deveria ser estudado em conexão com o art. 19 da mesma e com os arts. XI, XII, XIII, XV da Declaração Americana de Direitos Humanos e com os arts. 24, 28, 29 e 31 da Convenção sobre o Direito das Crianças (CORTE IDH. Caso "Instituto de Reeducación del Menor" vs. Paraguay, par. 253- 255).

${ }^{150}$ CORTE IDH. Caso Comunidad Indígena Yakye Axa vs. Paraguay, par. 162- 163.
} 
Também no caso Niñas Yean y Bosico vs. República Dominicana ${ }^{151}$, de 2005, a Corte ao referir-se sobre o dever de proteção especial das crianças, considerou que de acordo com o art. 19 da Convenção Americana, interpretado à luz da Convenção sobre os Direitos da Criança e do Protocolo de San Salvador, em relação com o dever de desenvolvimento progressivo previsto no art. 26 da Convenção Americana, o Estado tem o dever de prover educação primária gratuita a todos os menores, em um ambiente e condições propícias para seu pleno desenvolvimento intelectual $^{152}$.

Recentemente, no caso Acevedo Jaramillo e outros vs. Peru ${ }^{153}$ (2006) referente ao descumprimento por parte do Estado das sentenças que ordenavam a reintegração dos trabalhadores a seus postos de trabalho, os representantes das vítimas alegaram a violação do art. 26. Contudo, a Corte expressou que não analisaria a violação do mesmo, considerando que já havia se referido as graves conseqüências que teve o descumprimento das sentenças em relação aos direitos trabalhistas amparados nas mesmas. Assinalou, então, que estas conseqüências seriam levadas em conta pela Corte no momento de pronunciar-se sobre as reparações ${ }^{154}$.

Finalmente, no caso Trabajadores Cesados del Congreso vs. Peru, ${ }^{155}$ o qual os representantes da vítima também alegaram violação do art. 26, a Corte precisou que o objeto da sentença não era determinar o suposto caráter arbitrário das demissões das vítimas nem sua reposição, mas sim a violação das garantias judiciais e a proteção judicial em razão da falta de certeza acerca do recurso que poderiam dispor para reclamar seus direitos e

\footnotetext{
${ }^{151}$ Este caso refere-se, entre outros fatos, a uma criança que teve dificuldades de estudar, pois o Estado não lhe garantiu os direitos à nacionalidade e à personalidade jurídica (CORTE IDH. Caso de las Niñas Yean y Bosico vs. República Dominicana. Excepciones Preliminares, Fondo, Reparaciones y Costas. Sentença de 8 de setembro de 2005).

152 Ibid. par. 185.

153 CORTE IDH. Caso Acevedo Jaramillo y otros vs. Perú. Excepciones Preliminares, Fondo, Reparaciones y Costas. Sentença de 7 de fevereiro de 2006.

154 Ibid. pars. 285 a 286.

155 Este caso trata da demissão de 257 trabalhadores do Congresso Nacional da República do Peru que fazem parte de um grupo de 1117 trabalhadores que foram demitidos (do Congresso) através de resoluções do Congresso (CORTE IDH. Caso Trabajadores Cesados del Congreso (Aguado
} 
a existência de impedimentos normativos e práticos para um efetivo acesso a justiça. Assim, como no caso anterior, a Corte indicou que as violações a estas garantias necessariamente tiveram consequências prejudiciais para as vítimas, e reiterou que tais consequências seriam consideradas nas reparações $^{156}$.

Importante destacar o voto nesta sentença do juiz Cançado Trindade. Embora não tenha emitido sua opinião sobre o art. 26, reiterou seu entendimento no sentido de que todos os direitos humanos, inclusive os direitos econômicos, sociais e culturais, são imediatamente exigíveis e passíveis de justiciabilidade, uma vez que a inter-relação e indivisibilidade de todos os direitos humanos se afirmam não só no plano doutrinário mas também no plano operativo, - ou seja, tanto na doutrina como na hermêneutica e na aplicação dos direitos humanos ${ }^{157}$.

É notável, portanto, que o art. 26 da Convenção Americana não foi plenamente desenvolvido pela Corte. O caso Cinco pensionista vs. Peru tem, particularmente, despertado críticas doutrinárias. Tara Melish acredita que tal sentença desconhece todos os requisitos jurisdicionais do Sistema Interamericano, tanto aquele relativo ao dano concreto a pessoas determinadas quanto ao requisito da necessidade de um nexo causal com a conduta do Estado, ao referir-se somente “a crescente cobertura dos direitos econômicos, sociais e culturais sobre o conjunto da população”. Afirma, assim, que a maior ameaça para o litígio supranacional em matéria de direitos econômicos, sociais e culturais é a compreensão diferenciada dos órgãos do Sistema sobre a natureza das obrigações estatais aplicavéis ao capítulo III, “econômico, social e cultural”, em contraste com o capítulo II, “civis e políticos”158. Para a autora, este caso foi um desastre total para o

\footnotetext{
Alfaro y otros) vs. Perú. Excepciones Preliminares, Fondo, Reparaciones y Costas. Sentença de 24 de novembro de 2006).

156 Ibid. par. 136.

157 CORTE IDH. Caso Trabajadores Cesados del Congreso (Aguado Alfaro y otros) vs. Perú. Voto razonado del juez Cançado Trindade.

158 As obrigações aplicáveis ao capítulo III seriam aquelas relativas à "adoção de medidas progressivas" e para o capítulo II seriam as "medidas para respeitar e garantir os direitos", previstas nos arts. $1^{\circ}$ e $2^{\circ}$ da Convenção Americana (MELISH, T. Op.cit. (II), p. 214).
} 
litígio dos DESC e representa um verdadeiro desafio para os defensores de direitos humanos. Christian Courtis assume uma posição contrária ao entender que “obrigação de progressividade” pode ser alegada em casos individuais, embora admita a necessidade de se provar que a violação sofrida refere-se a uma situação generalizada ${ }^{159}$.

De acordo com as opiniões assinaladas, o dever de progressividade refere-se a população em geral, sem prejuízo de possíveis violações individuais pelo seu descumprimento. Observa-se que as controvérsias se relacionam mais com a justiciabilidade destas violações individuais do que com a natureza da obrigação (de progressividade).

De fato a definição da Corte adotada para interpretar o art. 26 é notoriamente imprecisa porque não define um padrão definitivo para determinar em que circunstância uma violação concreta de um direito econômico, social ou cultural pode representar infração do dever de progressividade. Além disso, a argumentação empregada pela Corte restringiu o entendimento do Comitê DESC da ONU, em sua observação geral número 3, a favor da justiciabilidade dos direitos econômicos, sociais e culturais. Segundo o Comitê, embora o Pacto Internacional dos Direitos Econômicos, Sociais e Culturais das Nações Unidas ${ }^{160}$ contemple uma realização paulatina e leve em consideração as restrições derivadas das limitações dos recursos disponíveis, também impõe várias obrigações de efeito imediato $^{161}$.

Por outro lado, é mister reconhecer que a Corte, neste caso, entendeu que a Convenção Americana consagra direitos sociais em seu art. 26 - no caso o direito à previdência social - ainda que tenha concentrado sua análise em uma interpretação do princípio da progressividade dentro de um caráter coletivo.

\footnotetext{
${ }^{159}$ COURTIS, Christian. La protección de los derechos económicos, sociales y culturales a través del artículo 26 de la Convención Americana sobre Derechos Humanos. San José, 2007, apud IIDH. Op.cit., p. 142.

${ }^{160}$ Adotado pela Resolução da Assembléia da Geral n. ${ }^{\circ}$ 2200-A (XXI) de 16 de Dezembro de 1966. Entrada em vigor: 3 jan. 1976.
} 
Lamentavelmente, os Cinco Pensionistas foi o único caso em que a Corte se pronunciou acerca do art. 26. Nos casos posteriores Yakie Axa vs. Paraguai e Niñas Yean y Bosico vs República Dominicana, o Tribunal vinculou a norma do art. 26 sobre a obrigação de desenvolvimento progressivo dos DESC com determinados direitos civis e políticos para determinar o alcance da responsabilidade estatal, como tradicionalmente faz com as obrigações gerais de respeito e garantia dos arts. $1^{\circ}$ e $2^{\circ}$ da Convenção. Esta opção é extremamente valiosa, mas poderia constituir na perda da autonomia dos direitos econômicos, sociais e culturais e dos elementos essenciais que os definem.

Finalmente, outra observação importante é o fato da Comissão Interamericana só ter alegado perante a Corte violação do art. 26 no caso Cinco Pensionistas, o que reduz a possibilidade do Tribunal tomar uma posição definitiva em relação a este artigo. Enquanto isso, a tendência é que os direitos econômicos, sociais e culturais sejam protegidos por meio dos direitos civis e políticos.

${ }^{161}$ Comitê dos Direitos Econômicos, Sociais e Culturais da ONU. Observação Geral No. 3: A índole das obrigações dos Estados partes. Ponto 1. 


\section{CONCLUSÃO}

O presente trabalho propôs-se a analisar de que forma a Corte Interamericana de Direitos Humanos tem conduzido sua jurisprudência para proteger os direitos econômicos, sociais e culturais. Como percebido no decorrer do estudo, a Corte apresenta uma posição promissora para garantir a efetiva proteção judicial destes direitos, vez que as demandas no continente americano e o avanço da doutrina em matéria de DESC são cada vez maiores. Além disso, a estrutura normativa do Sistema Interamericano apresenta importantes oportunidades para a proteção dos direitos em questão.

A Declaração Americana, a Convenção Americana e o Protocolo de San Salvador são os mais importantes instrumentos para a proteção dos direitos econômicos, sociais e culturais no Sistema Interamericano. A Corte tem considerado principalmente a Convenção para proteger os direitos supracitados e utiliza o Protocolo como instrumento interpretativo.

Conseqüentemente, através da interpretação dos direitos civis e políticos consagrados na Convenção, a Corte, em diversos casos, analisou elementos característicos dos direitos econômicos, sociais e culturais e possibilitou soluções importantes aos indivíduos e grupos que denunciaram a vulnerabilidade de seus direitos. Como analisado no capítulo II, a Corte ampliou o conteúdo dos direitos civis e políticos da Convenção Americana, por meio de ou no uso de uma interpretação pro homine, ao citar constantemente tanto instrumentos do Sistema Interamericano quanto outros que protejam direta ou indiretamente os direitos econômicos, sociais e culturais. Assim, o Protocolo de San Salvador, as normas da Convenção dos Direitos da Criança, o Comitê DESC das Nações Unidas, as Convenções da OIT, entre outros instrumentos, foram incorporados na argumentação da Corte para proteger o direito à vida, à integridade pessoal, à propriedade, etc. 
Desta forma, a Corte outorgou proteção tanto aos direitos civis e políticos quanto aos direitos econômicos, sociais e culturais. Ou seja, ao determinar a violação do direito à vida, a Corte considerou que o direito à saúde não foi observado; ou, ao interpretar o direito à vida em sua integralidade, conseguiu abarcar tanto aspectos civis e políticos como sociais, econômicos e culturais; ou outorgou reparações para proteger diretamente e imediatamente os DESC como o direito à educação e o direito ao trabalho.

De fato, a crescente jurisprudência da Corte sobre os direitos econômicos, sociais e culturais - desde os direitos indígenas à terra e à cultura, aos direitos trabalhistas e sindicais, às condições adequadas de saúde, alimentação e meio ambiente, à proteção da família e das crianças, etc. - indica claramente que a Corte não é reticente em resolver litígios referentes a DESC. Esses desenvolvimentos na busca de uma proteção eficaz dos referidos direitos, no âmbito da competência contenciosa da Corte, são testemunho da clara aceitação por este órgão da tese de interrelação e indivisibilidade dos direitos humanos.

A dificuldade está, no entanto, em estabelecer sua jurisprudência nos casos em que é alegada uma violação direta dos direitos econômicos, sociais e culturais. Com a leitura do marco normativo, poder-se-ia dizer que as alternativas de se exigir o cumprimento direto dos DESC oferecem importantes possibilidades de êxito. E, neste sentido, recentes estudos doutrinários contribuem para que os órgãos do Sistema Interamericano possam aplicá-los diretamente no âmbito de sua competência contenciosa.

No entanto, a Corte tem evitado se pronunciar acerca do art. 26 que protege os DESC na Convenção Americana, embora não tenha descartado a possibilidade de aplicá-lo. A dificuldade em desenvolver de forma consistente o alcance da obrigação de desenvolvimento progressivo reconhecida neste artigo e, da mesma forma, o conteúdo e alcance dos direitos econômicos, sociais e culturais dificultam a possibilidade da Comissão submeter à Corte demandas referentes às violações diretas dos 
direitos econômicos, sociais e culturais. No único caso, "Cinco Pensionistas" vs. Peru, em que a Comissão alegou perante a Corte a violação de um direito social por meio do art. 26, a sentença do Tribunal representou um forte obstáculo para se fazer cumprir os direitos econômicos, sociais e culturais no Sistema Interamericano.

Da mesma forma, os direitos sindicais e o direito à educação, previstos no Protocolo de San Salvador, que podem ser aplicados diretamente nos casos contenciosos, não foram, até o momento, considerados pela Corte. Mas foi utilizado para determinar o alcance de determinados direitos civis e políticos como o direito à vida no caso do Instituto de Reeducación del Menor e do direito à propriedade privada no caso dos "Cinco Pensionistas", entre outros.

A hesitação da Corte em proteger de forma autônoma os direitos econômicos, sociais e culturais implica a necessidade deste órgão continuar referindo-se aos mesmos mediante sentenças (denúncias) que se submetam a Corte alegando violações, fundamentalmente, sobre os direitos civis e políticos protegidos pelo referido instrumento. Não obstante o enorme potencial que esta prática tenha no Sistema Interamericano para a consagração dos direitos em pauta, a amplitude exagerada dada aos direitos civis e políticos pode diluir o seu sentido e ainda obscurecer as dimensões essenciais dos DESC. (muito bom)

Não se quer estabelecer no presente trabalho quais são as melhores formas para alcançar a justiciabilidade dos diretos econômicos, sociais e culturais na Corte Interamericana, mas sim compreender a forma com que este órgão busca a proteção dos DESC. Com efeito, pode-se afirmar que a jurisprudência da Corte, como um todo, é bastante positiva. (parágrafo deve ir para a introdução)

No entanto, a consagração no plano jurisprudencial de uma visão integrada dos direitos humanos não deve fazer abstração dos esforços de identificação, no plano normativo, da autonomia dos direitos econômicos, sociais e culturais, possibilitando a proteção direta destes direitos no plano 
processual. Embora não haja respostas definitivas, não deixa de ser alentador que a Corte já tenha dado início à possibilidade de se criar o alcance e conteúdo destes direitos. Muitas de suas sentenças têm contribuído no desenvolvimento de determinados direitos sociais, como o direito à saúde; direitos culturais, como os direitos indígenas à sua cultura; e direitos econômicos, como o direito à previdência social, mesmo sendo através dos direitos civis e políticos.

Nada impede que, em razão da própria indivisibilidade de todos os direitos humanos, determinados direitos econômicos, sociais e culturais básicos possam no futuro próximo vir a apresentar conteúdo autônomo (evitar nota em conclusão) em contextos específicos e concretos, e assim compor definitivamente os direitos e liberdades que os Estados Partes da Convenção Americana comprometeram-se a respeitar e garantir.

Finalmente, deve-se admitir que embora a estrutura normativa do Sistema Interamericano seja pródiga na proteção geral dos direitos econômicos, sociais e culturais, cumpre aos órgãos explorá-la e ativá-la para permitir a justiciabilidade destes direitos.

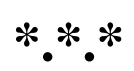




\section{BIBLIOGRAFIA}

MELISH, Tara. La Protección de los Derechos Económicos, Sociales y Culturales en el Sistema Interamericano de Derechos Humanos: Manual para la Presentación de Casos. Quito: Sergrafic, 2003. 526 p.

LEÃO, Renato Zerbini R. Os Direitos Econômicos, Sociais e Culturais na América Latina e o Protocolo de San Salvador. Porto Alegre: Ed. Sergio Antonio Fabris, 2001. 244 p.

CENTRO PELA JUSTIÇA E O DIREITO INTERNACIONAL (CEJIL). La Proteccion de los Derechos Económicos, Sociales y Culturales y el Sistema Interamericano. Costa Rica: Gossestra Intl., S.A, 2005. $105 \mathrm{p}$.

INSTITUTO INTERAMERICANO DE DERECHOS HUMANOS (IIDH). Protección Internacional de los Derechos Económicos Sociales y Culturales: Sistema Internacional y Sistema Interamericano. San José: Editorama S.A., 2008. 406 p.

CANÇADO TRINDADE, Antônio Augusto. Tratado de Direito Internacional dos Direitos Humanos, volume I. $2^{\mathrm{a}}$ edição. Porto Alegre: Sergio Antonio Fabris Editor, 2003. 663 p.

ABRAMOVICH, Victor e COURTIS, Christian apud BRICEÑO-DONN, Marcela; HURTADO, Michael Reed. Aportes para el litigio en materia de derechos económicos, sociales y culturales en el sistema interamericano de protección. Documento de trabalho produzido para a Plataforma Interamericana de Direitos Humanos, Democracia e Desenvolvimento, Bogotá, out. 2007. 55 p.

LEDESMA, Héctor Faúndez. Los derechos económicos, sociales y culturales en el Sistema Interamericano. In: VOLIO, Lorena Gonzáles (Coord.). El Sistema Interamericano de Protección de los Derechos Humanos: su jurisprudencia sobre debido proceso, DESC, libertad personal y libertad de expresión. Tomo II. San José: Editorama S.A., 2004. p. 90 - 180.

SALVIOLI, Fabián. La protección de los derechos económicos, sociales y culturales en el sistema interamericano. In: Revista Instituto Interamericano de Direitos Humanos. San José, No. 39, p. 101 167, jan./jun. 2004.

ROBLES, Manuel Ventura. Jurisprudencia de la Corte Interamericana de Derechos Humanos en materia de derechos económicos, sociales y 
culturales. In: Revista Intistituto Interamericano de Derechos Humanos. San José, No. 40, p. 87 - 131, 2004.

BONILLA, Carlos Rafael Urquilla. Los derechos económicos, sociales y culturales en el contexto de la reforma al sistema interamericano de protección de los derechos humanos. In: Revista Interamericana de Derechos Humanos. San José, No 30.31, p. 98 - 150, 1999.

CORTE IDH. Informe Anual de la Corte Interamericana de Derechos Humanos 1986, OEA/Ser.L/III, 15 Doc. 13, 1986.

\section{Documentos eletrônicos}

MELISH, Tara. El litigio supranacional de los derechos económicos, sociales y culturales: avances y retrocesos en el Sistema Interamericano. Disponível em:

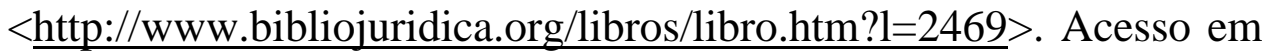
28 maio 2008.

MELISH, Tara. El litigio supranacional de los derechos económicos, sociales y culturales: avances $y$ retrocesos en el Sistema Interamericana. Disponível em: $<\underline{\text { http://www.bibliojuridica.org/libros/libro.htm?l=2469 }}>$. Acesso em 28 maio 2008.

KRSTICEVIC, Viviana. La tutela de los derechos sociales en el sistema interamericano. Disponível em: $<$ http://www.idrc.ca/openebooks/323-2/\#page_171>. Acesso em 28 maio 2008.

MELISH, Tara. The Inter-American Court of Human Rights: Beyond Progressivity. Disponível em: <http://ssrn.com/abstract=1000265>. Acesso em 28 maio 2008.

ABRAMOVICH, Víctor e ROSSI, Julieta. La tutela de los derechos económicos, sociales y culturales en el artículo 26 de la Convención Americana sobre Derechos Humanos. Disponível em: $<\underline{\text { http://dialnet.unirioja.es/servlet/articulo?codigo=2354628 }}>$. Acesso em 28 maio 2008.

RAMÍREZ, Sergio García. Protección jurisdiccional internacional de los derechos económicos, sociales y culturales. p. 139-141. Disponível em: $\quad<$ http://dialnet.unirioja.es/servlet/articulo?codigo=624566 $>$. Acesso em: 28 maio 2008. 
QUIROGA, Cecília Medina. Las obligaciones de los Estados bajo la Convención Americana de Derechos Humanos. Disponível em: $<$ http://www.corteidh.or.cr/libros.cfm>. Acesso em 28 maio 2008.

\section{Jurisprudência}

CORTE IDH. Opinión Consultiva OC-10/89: Interpretación de la Declaración Americana de los Derechos y Deberes del Hombre en el Marco del Artículo 64 de la Convención Americana sobre Derechos Humanos, Serie A No. 10, 14 jul. 1989.

CORTE IDH. Opinión Consultiva OC- 4/84. Propuesta de Modificación a la Constitución Política de Costa Rica Relacionada con la Naturalización, Serie A No. 4, 19 jan. 1984.

CORTE IDH. Opinión Consultiva OC-1/82. "Otros Tratados” Objeto de la Función Consultiva de la Corte (art. 64 Convención Americana sobre Derechos Humanos), Serie A No. 1, 24 set. 1982.

CORTE IDH. Opinión Consultiva OC-17/02. Condición Jurídica y Derechos Humanos del Niño, Serie A No. 17, 28 ago. 2002.

CORTE IDH. Opinión Consultiva OC-16/99. El Derecho a la Información sobre la Asistencia Consular en el Marco de las Garantías del Debido Proceso Legal, Serie A No. 16, 1 out. 1999.

CORTE IDH. Caso Loayza Tamayo Vs. Perú. Fondo. Sentença de 17 de Setembro de 1997. Serie C No. 33.

CORTE IDH. Caso de los "Niños de la Calle" (Villagrán Morales y otros) Vs. Guatemala. Fondo. Sentença de 19 de novembro de 1999. Serie C No. 63.

CORTE IDH. Caso "Instituto de Reeducación del Menor" Vs. Paraguay. Excepciones Preliminares, Fondo, Reparaciones y Costas. Sentença de 2 de setembro de 2004. Serie C No. 112.

CORTE IDH. Caso Comunidad Indígena Yakye Axa Vs. Paraguay. Fondo Reparaciones y Costas. Sentença 17 de junho de 2005. Serie C No. 125.

CORTE IDH. Caso Comunidad Indígena Sawhoyamaxa Vs. Paraguay. Fondo, Reparaciones y Costas. Sentença de 29 de março de 2006. Serie C No. 146. 
CORTE IDH. Caso Ximenes Lopes Vs. Brasil. Fondo, Reparaciones y Costas. Sentença de 4 de julho de 2006. Serie C No. 149.

CORTE IDH. Caso Albán Cornejo y otros. Vs. Ecuador. Fondo Reparaciones y Costas. Sentença de 22 de novembro de 2007. Serie C No. 171.

CORTE IDH. Caso de la Comunidad Mayagna (Sumo) Awas Tingni Vs. Nicaragua. Fondo, Reparaciones y Costas. Sentença de 31 de agosto de 2001. Serie C No. 79.

CORTE IDH. Caso del Pueblo Saramaka. Vs. Surinam. Excepción Preliminar, Fondo, Reparaciones y Costas. Sentença de 28 de novembro de 2007. Serie C No. 172.

CORTE IDH. Caso Baena Ricardo y otros Vs. Panama.

Fondo,Reparaciones y Costas. Sentença de 2 de fevereiro de 2001. Serie C No. 72.

CORTE IDH. Caso Huilca Tecse Vs. Perú. Fondo, Reparaciones y Costas. Sentença de 03 de março de 2005. Serie C No. 121.

CORTE IDH. Caso Cantoral Huamaní y García Santa Cruz Vs. Perú Excepción Preliminar, Fondo, Reparaciones y Costas. Sentença de 10 de julho de 2007. Serie C No. 167

CORTE IDH. Caso "Cinco Pensionistas" Vs. Perú. Fondo, Reparaciones y Costas. Sentença de 28 de fevereiro de 2003. Serie C No. 98.

CORTE IDH. Opinión Consultiva OC-14/94. Responsabilidad Internacional por Expedición y Aplicación de Leyes Violatorias de la Convención (arts. 1 y 2, Convención Americana sobre Derechos Humanos), Serie A No. 14, 9 dez 1994.

CORTE IDH. Caso de las Niñas Yean y Bosico Vs. República Dominicana Excepciones Preliminares, Fondo, Reparaciones y Costas. Sentença de 8 de setembro de 2005. Serie C No. 130.

CORTE IDH. Caso Acevedo Jaramillo y otros Vs. Perú. Excepciones Preliminares, Fondo, Reparaciones y Costas. Sentença de 7 de fevereiro de 2006. Serie C No. 144.

CORTE IDH. Caso Trabajadores Cesados del Congreso (Aguado Alfaro y otros) Vs. Perú. Excepciones Preliminares, Fondo, Reparaciones y Costas. Sentença de 24 de novembro de 2006. Serie C No. 158. 
CIDH. Informe N ${ }^{\circ}$. 29/01, Caso 12.249, Jorge Odir Miranda Cortez, El Salvador, 7 mar. 2001. 